\title{
Making a Vegetable-Garden
}

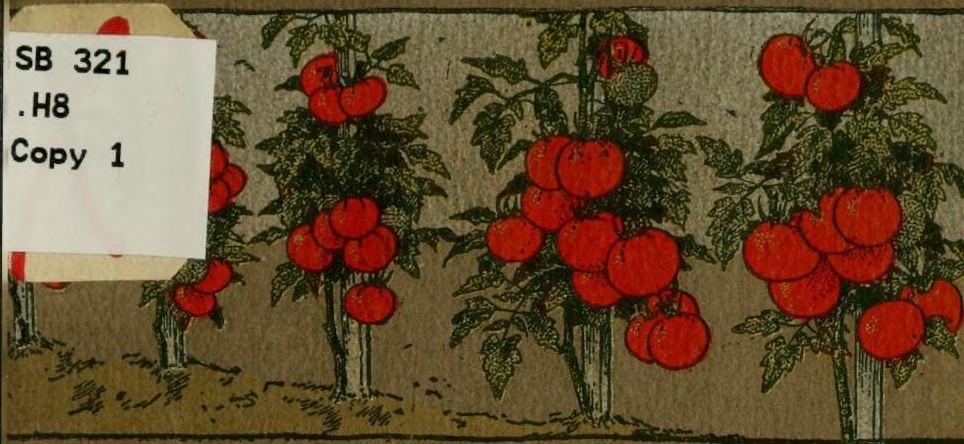

\section{THE COUNTRYSIDE HANDBOOKS}




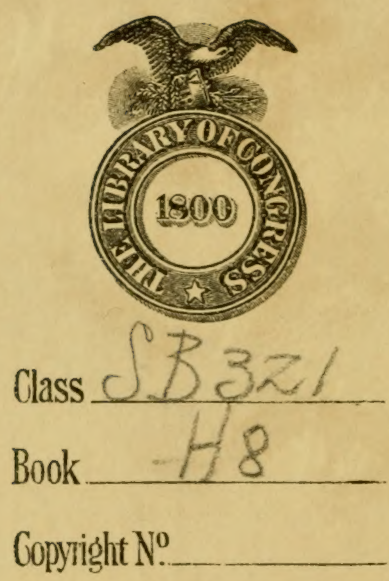

COPYRIGHT DEPOSIT. 




\section{HOW TO MAKE A VEGETABLE-GARDEN ·}


THE COUNTRYSIDE PRESS BOOK PUBLISHERS HARRISBURG, PA. 



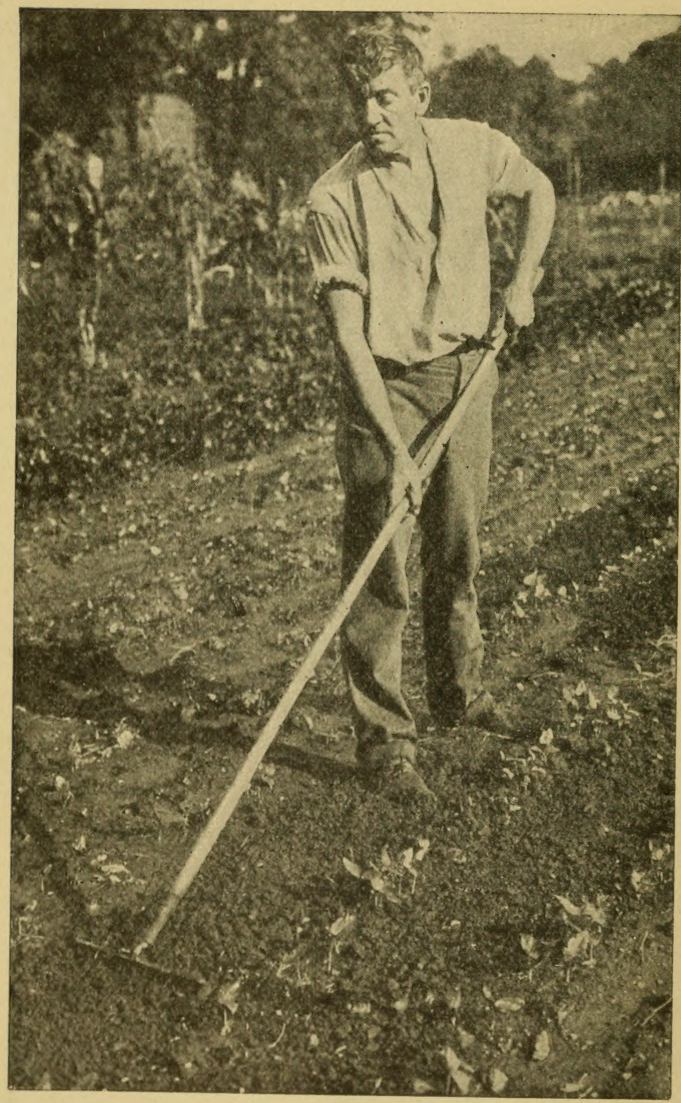

Clean culture means success 


\section{HOW TO MAKE A VEGETABLE-GARDEN}

\section{ILLUSTRATED AND WITH PLANTING TABLES}

HARRISBURG, PA. THE COUNTRYSIDE PRESS

$$
1915
$$




\section{$5 B 321$}

COPYRIGHT, 1909, 1911, 1914, вY THE SUBURBAN PRESS

Copyright, 1915, ву THE COUNTRYSIDE PRESS

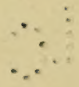

(C) CI.A416443. 


\section{TABLE OH CONTENTS}

PAGL

INTRODUCTION . . . . . . . . . . . . . . . . . 9

Planning and Planting . . . . . . . . . . . . 11

Plan for Variety and Table Quality . . . . . . . . . . 11

The Things to be Done . . . . . . . . . . . 13

Making the Plan . . . . . . . . . . . . . 13

Supplying Plant-food . . . . . . . . . . 16

Preparing the Soil . . . . . . . . . . . . 17

Sowing and Planting . . . . . . . . . . . . 19

Using the Seed Drill . . . . . . . . . . . 22

A Tegetable-Garden for a Family of Six . . . . 24

A Coldframe is Useful . . . . . . . . . . . . . 26

Rotation of Crops Desirable . . . . . . . . . . 27

Suggestions for Succession . . . . . . . . . . . 28

Nine Vegetables Every Man Ought to Grow . . . 30

The Late-started Garden . . . . . . . . . . . . . 39

Keep Lettuce Out of the Sun . . . . . . . . . . . . 40

Beets Sown in June Mature in August . . . . . . . . 42

Get in Some Melons and Cucumbers . . . . . . . . 43

The Garden Month by Month . . . . . . . . . 46

Planting Table for Vegetables . . . . . . . 62-73 



\section{INTRODUCTION}

THE part that gumption-just the plain, everyday quality of common sense-plays in gardening is so large that it should be written in this connection with a big G. If you had digested the most elaborate treatises on the subject of gardening, procured the most expensive tools and seeds and the finest soil and fertilizers, and did not with them use gumption, your gardening operations would be very likely to result in failure.

Way down deep in almost all of us the gardening instinct is struggling for expression. We feel that we would like to be the instruments for producing from the soil the means of sustenance that there may be in the form of vegetables. And yet a lot of good folk hold back from attempting a garden because they feel that it is too complicated an affair. They would freely give the toil necessary, but they are afraid they lack the "know-how." Gardening for the amateur, it should be most emphatically stated again, is largely a matter of gumption. In the pages that follow are given brief directions for some of the 
essential operations, together with seed and planting tables and the like. Mix these thoroughly with gumption, add a little toil, and you will have a garden that will not only give you much joy, but will return you a profit in actual money saved.

Much of this material originally appeared in magazine articles, and is used by permission of the publishers.

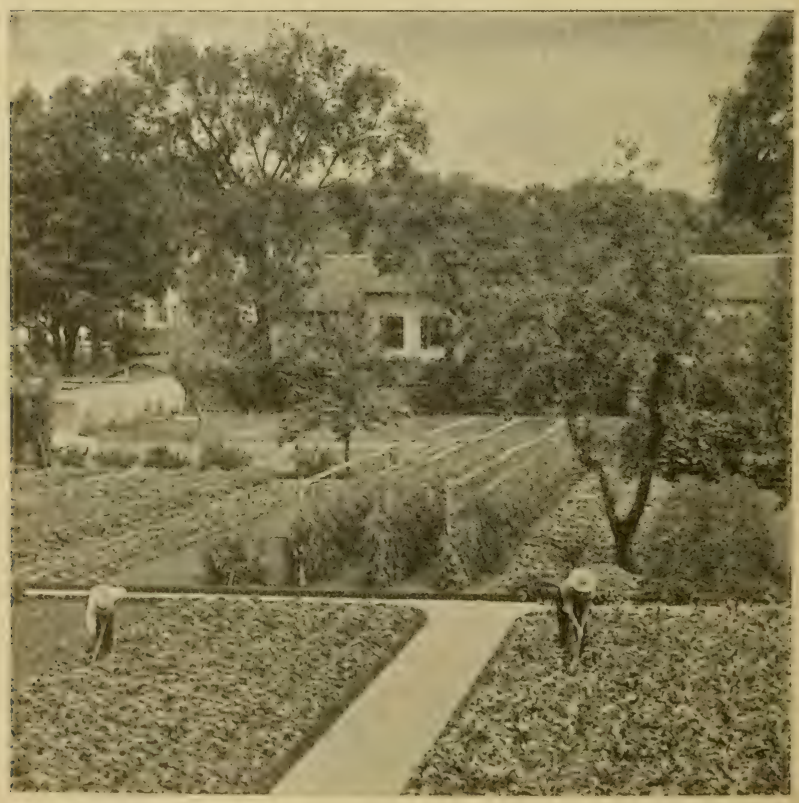




\section{HOW TO MAKE A VEGETABLE- GARDEN}

\section{PLANNING AND PLANTING}

A MISTAKE too frequently made on the A country place is to leave the planning and planting of the garden, which is to furnish the season's supply of fresh vegetables, to some man who, though he may know how to grow things, has not given the particular needs and requirements of your table the study and careful planning which are necessary to make possible a really satisfactory garden.

The planning of the garden, and at least the supervision of the planting of it, should have your personal attention. It is a job that is well worth looking after, for a great deal of the pleasure of the whole season will depend upon the amount and the quality of the green things which your garden furnishes for the table. And, incidentally, the very considerable saving which a really good garden makes in the season's household expenses is not to be ignored.

\section{PLAN FOR VARIETY AND TABLE QUALITY}

In making your garden plans, you should keep constantly in mind these two things: First, that the 
really good things of the garden-the ones that make you chuckle to yourself as you sit down, unroll your napkin and remark, "Mother never had anything on this;" the juicy, luscious, is-there-anymore-in-the-kitchen? things, like Crolden Bantam sweet corn, Mignonette lettuce, Brittle Wax beans, Gradus peas, or spicy cantaloupe, should be had for just as many weeks out of the season as it is possible to have them,-there are only seven dinnors in a week! The second is table quality; whether in the aristocratic stuffed pepper or in the plebeian sterved onion, this is not a matter of chance, but depends upon rapid, healthy growth, and the variety.

Unfortunately, most of the garden's good things either grow and mature very quickly, and are in the best table condition for a very short period only, such as peas, pod-beans, lettuce, and sweet corn, or else require such an exasperatingly long time that we just get a little taste of them at the tail end of the season, such as lima beans, eggplant, and muskmelons. The only way to overcome these regrettable shorteomings on Dame Nature's part is to have the garden planned so carefully, by the selection of succession varicties and accurately timed succession plantings, that as soon as one crop is gone another will be ready, and, in the case of the long-season things, to have them half-grown by the time you set them out, so that they will be nearly ready to show their first buds by the time your neighbors are putting their serels in the ground. so you see this garden business isn't such a simple 
thing after all, and further, that it has possibilities of which perhaps you have never dreamed. But now that we have a fairly clear idea of what is to be done, let us see what are most definite, concrete instructions we can get how to do it.

\section{THE THINGS TO BE DONE}

Here are the things to be done, and a few hours of decently hard thought and work, if you have someone to carry out your instructions, will give you a real garden,- - one full not only of spinach and beans, but of entrancing interest also, gratifying not only to the inner man, but to the keener palate of the intellect.

To make the information and data here placed at your disposal as definite and clear as possible, it has been put down under four headings, as follows: (1) Making the Plan, (2) Supplying the Plant-Food, (3) Preparing the Soil, (4) Sowing and Planting. To bring them all within the scope of a small book, it has been necessary to make them brief, and omit detailed reasons why. So, if you are going to follow them at all, follow them carefully, so that no important things will be overlooked.

\section{MAKING THE PLAN}

First of all, set down in a column the vegetables you will want, and the number of rows of each you will require. Remember that some things, like 
Swiss chard, which yields continuously, should be planted sparingly, compared to peas or sweet corn, which require much more room, and yield only two or three pickings. Also, that such things as onions, beets, and cablage, which may be stored for the winter, should be sown more generously than eucumbers or peppers, which succumb to the first frosts.

After each vegetable, put down the varieties you prefer. Those mentioned in the table are good, reliable sorts; if, however, you have favorite sorts of different things which are equally good, use them instead of these, if you like. Don't make the mistake of trying a little of everything.

Then, if you want to do the job up properly, draw a plan of your garden to scale, showing the amount of space you have allotted for each vegetable. This can be done very rapidly, as the proper distance between the rows of things is given in the tables on pages 62 to 73 . This will not only give you a much better idea of what your garden will be like, but will enable you to judge much better as to the proportionate amount of space you may allot to each thing. In case your garden space is very limited, and you have to plan carefully in order to get two or even three crops off of most of it during the season, it is not only desirable but quite essential to make this plan. The time and trouble taken to prepare it will be repaid a score of times by the amount of time and trouble it will save you during the season. Such a plan is simply the application of the principles of business efficiency to the garden. 


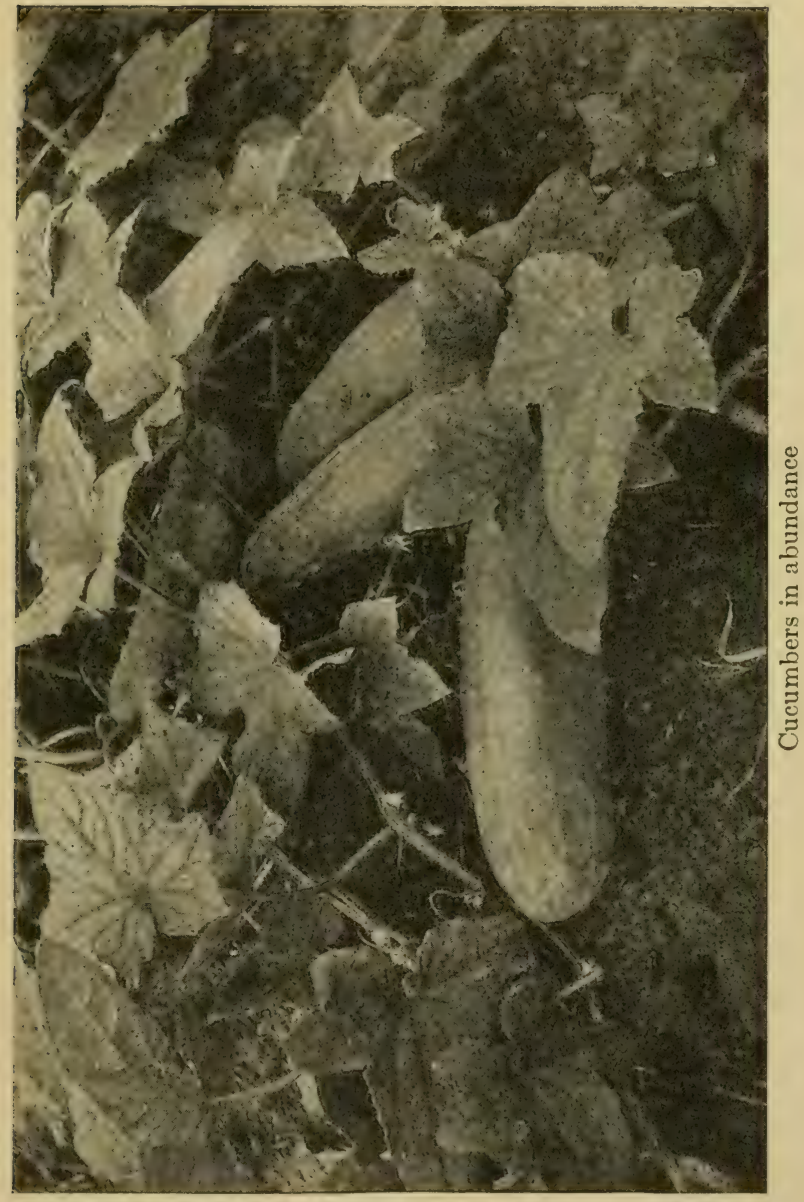




\section{SUPPLYING PLANT-FOOD}

Without rich soil, the garden will be a poor one. Soil is not rich, in the sense of being in a condition to grow big crops, unless it contains the several ingredients necessary to support plant-life in abundance and in the proper proportions. Without getting into the technicalities of the matter at all, it may be stated that every gardener, or person who has a garden, should make himself or herself familiar with the fact that the three of these ingredients which are most important, and which are most likely to be deficient in the soil, are nitrogen, phosphoric acid, and potash. If your garden is not already rich enough,-and most soils are not nearly in a condition to grow big crops without being fed up first, - these three things must be abundantly supplied. They can be supplied in any one of a number of ways, but should not be stinted. A safe rule is to use all the good, well-rotted stable-manure you can get, and in addition to this some fertilizer with a high percentage of potash, or sulphate or muriate of potash alone; 300 to 500 pounds of the former fertilizer, or 150 to 300 pounds of either sulphate or muriate, for each half-acre, will be none too much. If you can't get any manure, apply a dresing at the rate of 600 to 1,000 pounds to the half-acre of a high-grade fertilizer, with an analysis approximating 4 per cent of nitrogen, 8 per cent of available phosphoric acid, and 10 per cent of potash. If you will require a quantity above 300 or 400 
pounds, much the best and cheapest way is to get the chemicals and raw materials, and mix your own. (For instance, nitrate of soda, muriate of potash, 16 per cent acid phosphate, and high-grade animal tankage, used in the proportion of $30,40,50$, and $60 \mathrm{lbs}$. respectively, will give you a complete, high-grade fertilizer, as good as any market-garden fertilizer, with an analysis of approximately 4 per cent nitrogen, 8 per cent phosphoric acid, and 10 per cent potash.)

The manure or fertilizer, as the case may be, is worked into the soil before the garden is planted. In addition to these, you should get a hundred pounds or so each of nitrate of soda, and of muriate or sulphate of potash, to use as top-dressings for crops requiring special attention during growth. The former, especially, when judiciously used, will produce most astonishing results; all the nitrogen in it is quickly available, and plant growth is quite wonderfully hastened; thus increasing not only the output, but, in most instances, the quality of the crop also.

\section{PREPARING THE SOIL FOR PLANTING}

"A field well prepared is a crop half-grown," is an old farmer's saying which is just as true of the back-yard garden as of the twenty-acre potato field. There is no mistake more universally made by the managers of small gardens than that of planting in soil which is but ill prepared. The garden should be plowed or spaded as deep as possible, plowing being 


\section{1s HOW TO MAKE A VEGETABLE-GARDEN}

far preferable where it is possible to use a horse. By as "deep as possible" is meant down to the subsoil, if that is anywhere within 12 inches of the top. The subsoil is the raw dirt, usually hard and lumpy,

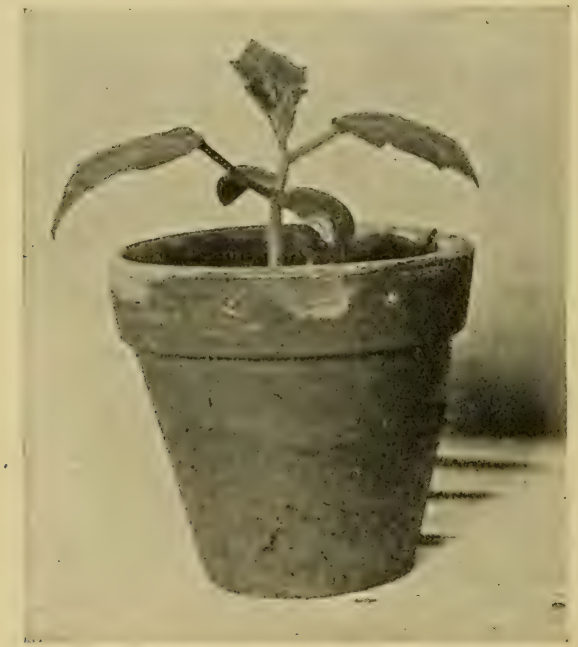

Cucumbers started in pots for transplanting outside later will enable you to gain time

and of a different color from the surface soil, and lies just below the latter. A little of it, if the surface soil is shallow, should be worked up and mixed with the latter each year, but not in sufficient quantity to have any great effect upen its character. Manure is best applied before plowing or spading, so that it (an be turned under, down out of the way of the 
seed drill and various garden implements, and fertilizer should be applied after plowing, and before harrowing or raking. Thorough harrowing or raking is just as necessary as thorough plowing or spading; both jobs must be well done in order to prepare a good seed-bed. When you are ready to plant, your garden should be as clean and smooth on top as a tennis-court, and pulverized finely for several inches below the surface. There is not room to tell you fully why such careful preparation of the soil is necessary; but the three most important reasons are that seed will not germinate properly in a poorly prepared, lumpy soil, full of air-spaces; that plant-roots will not be able to get hold of their food supply so readily in such a soil as in one well prepared; and that, next July or August, when the drought hits you, a thoroughly prepared soil is likely to mean all the difference between success and failure.

\section{SOWING AND PLANTING}

Unless you have been through the interesting operation of garden planting frequently enough so that the various details of the work have become almost second nature to you, follow carefully the planting data. in the table on pages 62 to 73 , plus any special information which may be given as to kind and variety of vegetable on the package or in the catalogue. Many of the failures which beginners have every year are due merely to carelessness in just this matter. If you need to refer to the table 
frequently, you will find it a good plan to copy the planting data on a piece of paper, paste it on a heavy cardboard, and tack it up in the tool-chest, or some place near the garden where you keep your seeds, so that you can refer to it readily, or take it right out into the garden with you, if you wish.

The planting dates given are for the latitude of New York. For Boston, they will be a week or ten days later, and for Philadelphia, or farther south, a week or ten days earlier. They are approximate, because temporary weather conditions, the character of the soil in which the garden is made, and the nature of the season, whether an early or a late spring, will all go to determine when would be the proper time to plant.

The different vegetables are planted in drills, rows, or hills, as may be required by their habit of growth. The least desirable method is in hills, because, while it is bad to have the plants crowded above ground, it is still worse to have the roots restricted, instear of being distributed as evenly as possible throughout the soil, that their search for plant-food may be unhampered. Such things as pole beans and melons, which formerly were always planted in hills, do better in drills or rows so that there is no crowding of plants. Beans, tomatoes, and other trailing or rumning plants will give larger and better (rops if trained on a trellis than on poles.

Another thing that you will notice is that the depth for planting varies with early and late plantings of the same things. The reason for this is that 

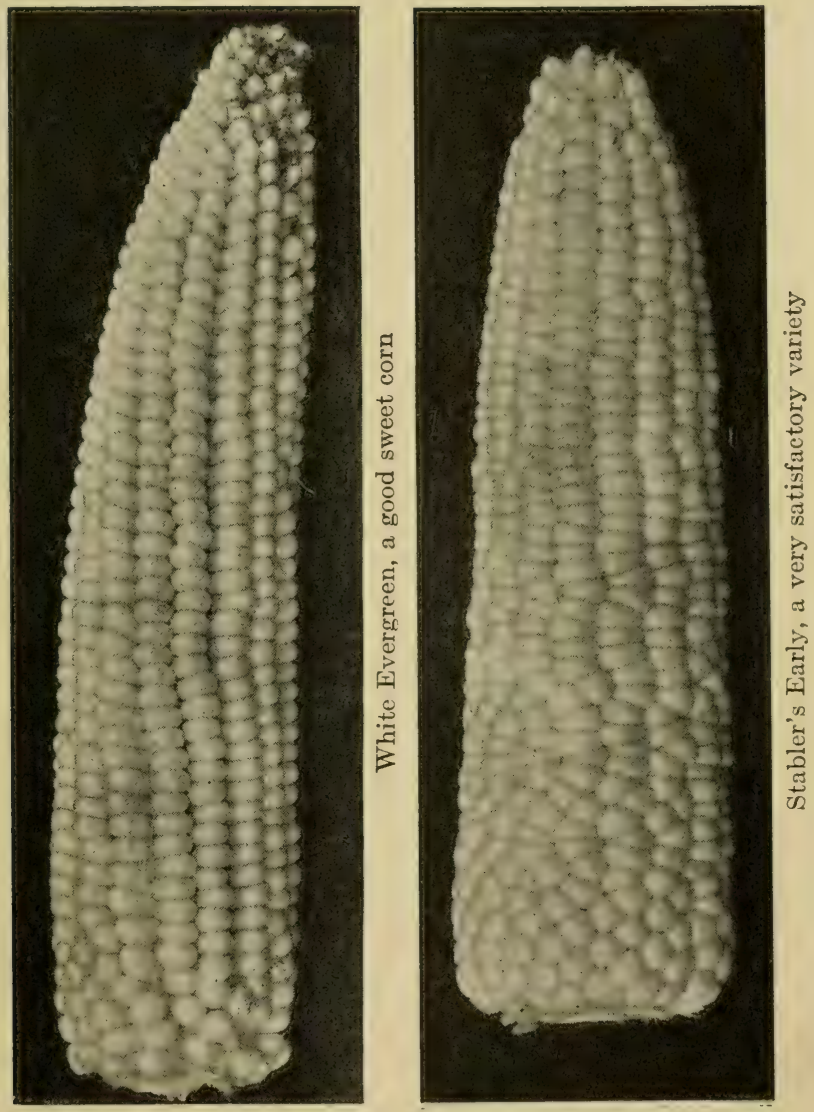
the soil warms in the spring more rapidly on the surface, and seed will germinate and sprout all right when planted shallow, which would rot if planted deeper. Later in the season, however, when the soil on the surface has become too hot and dry for proper germination, the right conditions are found deeper in the soil, and the plant is also in a better position to resist the attack of drought which is pretty sure to come later.

\section{USING THE SEED DRILL}

In these days, the only practical way of planting a garden of any size is to use a seed drill, which opens the furrows, drops the seed, accurately covers it up, rolls it, and marks out the next row all in one operation, and much better than it can be done by hand. Where; however, the seed for any reason must be put in by hand, the drills or rows should be hoed or marked out to the proper depth as evenly as possible, the seed planted and covered before the soil has a chance to dry out, and the top of the row pressed down by the foot or the back of the hoe, both to compress the earth and to mark the row.

Be sure to get all rows straight as a string; the only way to do this is to use a string in marking out the first one; after that, if you are using a drill, the others will all be parallel with it. In making hills for such things as pole beans, muskmelons, and cucumbers, unless the garden soil has been made very rich, it is well to put in a compost of well- 
rotted manure, or a handful or more of a mixture of cotton-seed meal or bone meal and tankage, mixed well into the soil in each hill before planting. The hill should be broad and flat, 12 to 24 inches in diameter, and not raised above the surface of the surrounding soil, so that the rain will not run off from it.

In setting out plants of such things as are started carly under glass-lettuce, cabbage, tomatoes, eggplant, and the like-prepare the soil just as carefully as you would for sowing seèd. If you want to give the plants a quick start, a handful or so of dry hen manure, of bone meal, tankage, or cotton-seed meal (or the three mixed together, as suggested before), or a half a pint of rich liquid manure, may be put into the soil where each plant is to be set, before planting. Select a late afternoon or a cloudy day, if possible, to do the work. If the leaves of the plant to be set are large and succulent, they should be trimmed back a third to a half before being set out. Be sure, above all things, to set the plants firmly into the soil. Set them deep enough so that about half the stalk, up to the first leaves, will be covered. Press the soil down about the ball of roots as firmly as possible, and then after the row is set, unless the soil is very moist, go back over it and, with the balls of the feet placed on either side of the stem of the plant, press them in still more firmly. This operation will take very little time, and leave the job done properly; you will find later that the time expended on it is worth while. 


\section{A VEGETABLE-GARDEN FOR A FAMILY OF SIX}

The size of one's vegetable-garden should naturally depend upon the size of the family to be fed, as well as upon the number and kinds of vegetables it is desired to grow. The plan shown on page 25 is for a garden sufficiently large to grow enough vegetables for a family of six. It covers about a quarter of an acre, the exact dimensions being $75 \times 150$ feet.

The garden is laid out with the idea of cultivating the land with a horse cultivator; the rows, in some instances, could be closer together if a hand wheel hoe only were to be used. In the latter case, onions, lettuce, beets, and carrots could be grown as close as 18 inches or 2 feet apart very comfortably, thereby saving considerable room.

In the laying out of a vegetable-garden, it is better, under most circumstances, to have the rows run the short way of the garden if it is to be cultivated with a wheel hoe. Should it be a long, narrow piece, then the rows may run the long way, so that there will not be so much waste space at the ends of the rows. A certain amount of ground not planted is really necessary at the ends for turning when a horse and eultivator are used. It is far better to have the rows run north and south, so that each side of the row gets an equal amount of light.

Of course, the plan here given is included for its suggestive value, and need not be exactly followed in every detail. 


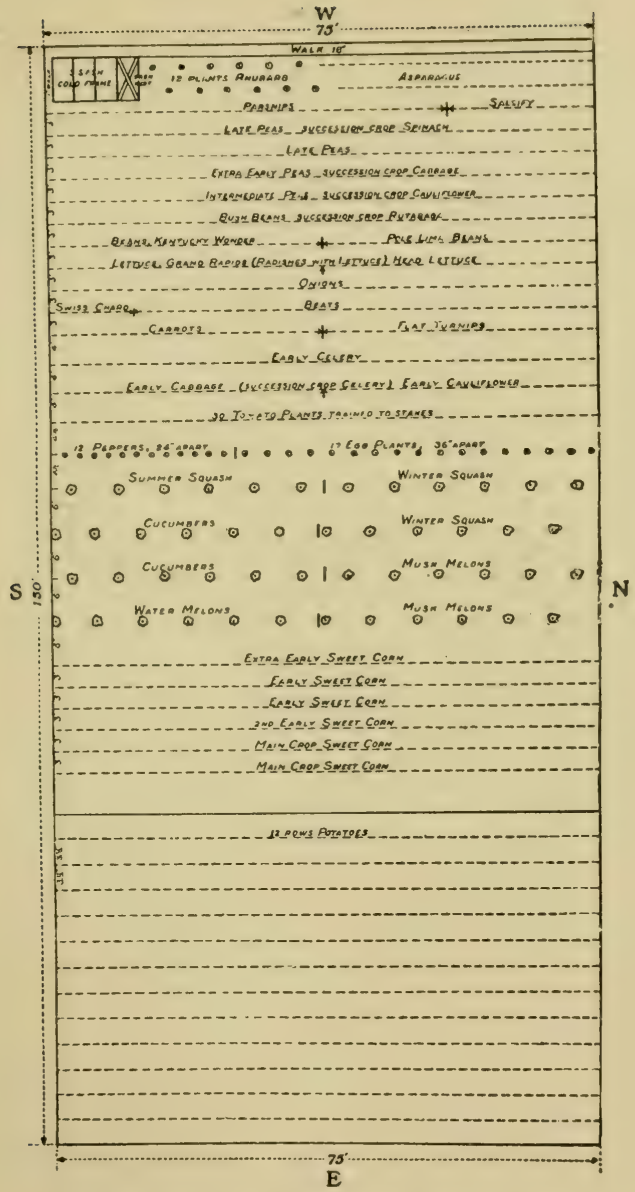

A well-arranged garden for a family of six 


\section{A COLDFRAME IS USEFUL}

Provision in this garden is made for a three-sash coldframe. This is not absolutely essential, but very useful, for there are many vegetables that one can start early in the coldframe, such as cabbage, cauliflower, onions, and celery, for planting for early crops, and lettuce and radishes for immediate use. Three sashes will be ample for an ordinary family. At the end of the frame there has been allowed a space in which to stack the sashes, and if shutters and mats are used to cover the sash, they can also be stored here.

In the same end of the garden, asparagus and rhubarb are planted. Like the coldframe, they are permanent. A dozen plants of rhubarb will provide all of that vegetable necessary.

The balance of the end of the garden is devoted to asparagus. Early in the season it may be found that this number of plants will not give sufficient asparagus for the family, but that will only be for a week or two, for the rest of the season there will be some to give away.

A row of parsnips and salsify comes next; they are hardy vegetables which may be left in the ground all winter. It is a most practicable plan to keep everything which is going to be wintered over outdoors close together for convenience. They can be harvested more readily, and the rest of the garden can be cleaned up at the season's end without interfering with them. 


\section{ROTATION OF CROPS DESIRABLE}

The remaining space may be planted with whatever vegetables are desired, but it is better to keep all the plants of the same family in a group by themselves, making rotation of the crops a simple matter. It is not only easier on the land to practice rotation, but this plan tends to avoid trouble from insects, and to reduce the trouble from plant diseases, as well, as some of these pests winter over in the ground where the plants which they infested the previous summer were grown. For instance, cabbage, cauliflower, and turnips should never be grown two successive seasons on the same ground because of the trouble from club-root. The same rules apply to potatoes, because the potato scab winters over. Of course, if you have not grown any scabl)y potatoes, and you are careful to disinfect your seed each year before planting, there will be less trouble from this cause; and really, when one has only a small piece of land, every precaution against such troubles should be taken.

An effort has been made to show in the plan where everything ought to go; but little things, like radishes for instance, can be grown in between other plants, and therefore space for them need not be indicated. It is a good plan to sow radish seed in the row with the lettuce. The radishes will be up in a few days and will be ready to pull long before they are in the way of the lettuce plants.

A whole row of beans is shown, but do not plant 
these all at once. Make two plantings a week apart. This will make a succession which will be maintained until the pole beans come in, and, once they have commenced to produce, one need not bother about the bush sorts any longer because one can get varieties of the pole beans that are just as good for snap beans as are the dwarf kinds.

\section{SUGGESTIONS FOR SUCCESSIONS}

The successions indicated on the plan may not be convenient for the gardener who tries to follow them. They are given only as suggestions, but the early peas are off the ground so early that it would be a shame to allow that portion of the garden to lie idle the rest of the season. Therefore some late crop, like cabbage, cauliflower, celery, rutabaga, or spinach for the following season's crop, can be planted.

Some people will probably find fault with this plan because all of the cucurbits - squashes, melons, etc.-are planted in adjoining rows. Do not for an instant think that because squashes, cucumbers, and melons are growing side by side that the presence of one is going to affect in any way the flavor of the others. There have been cases where growers tried to lay the poor quality of fruit from the vines to this cause, when, in reality, it was due to poor varieties in the first place, a lack of attention or poor cultivation, all of which could have been avoided.

On the plan has been indicated a single row of tomato plants, set 2 feet apart and trained to sticks, 
because many gardeners like to raise tomatoes this way. But should one prefer to grow his tomatoes on trellises, two and one-half rows could be devoted to the tomato plants, A-trellises being set between the rows for the tomatoes to climb over, and the other half of the two rows being devoted to peppers and eggplant.

The row of onions, as indicated, can be planted as one wishes. It would be a wise move to plant the whole row of one of the large kinds, like Prizetaker or Ailsa Craig. To grow these onions to perfection, they should be started in the coldframe late in February, or early in March, and transplanted to the open garden when they are about the size of lead-pencils. There is a distinct advantage in transplanting onions this way. If the soil is sterile in the coldframes, there will be no danger of the young plants being infested with smut. Also, there will be no trouble with this disease on the onions after they they have been transferred to the open garden; for the smut, from all reports, is unable to gain an entrance into the onion plant after it has attained any size at all. It is only at the time of germination, when the stems are very tender, that this pest gains entrance. These varieties are bigger and milder, and, many people think, superior to the ordinary onions, like Yellow Danvers. One could use a portion of the row for growing onion sets, scallions, or the like.

The potato patch on one end of the garden is optional, for one can buy just as good potatoes as he can grow. Such is not the case, however, with 
sweet corn, cucumbers, peas, beans, and similar vegetables. This space is capable of raising something like ten to twelve bushels of potatoes, if it is well fertilized and carefully cultivated all summer long, and this will be enough to last an ordinary family through a year.

\section{NINE VEGETABLES EVERY MAN OUGHT TO GROW}

The amateur gardener, no matter how small his plot, can grow a few of several kinds of vegetables that always are better when they come directly from the ground to the kitchen.

All are easy to grow, if the brief directions given here and in the planting tables on pages 62 to 73 are followed.

If you want to have good radishes, you must grow them quickly. They do well in a light soil, if it is well enriched, and most of the early varieties will be ready to pull in three to five weeks from sowing. A succession must be maintained by sowing every two weeks. Sow them thickly in drills from 12 to 18 inches apart, and then thin them out. A good early variety is Early Scarlet Turnip Forcing; French Breakfast and Long Scarlet are also good early varieties.

Lettuce should be grown in every garden. There is a peculiar delight in having this vegetable fresh from the soil, with a crispness and freshness that "boughten" lettuce never has. It is easy to grow. 
The very early spring crop must be started in the coldframe in March, but sowings may be made in the open from April to Octoher. Lettuce requires a rich and moist soil, with fertilizers containing much nitrogen and that act quickly.

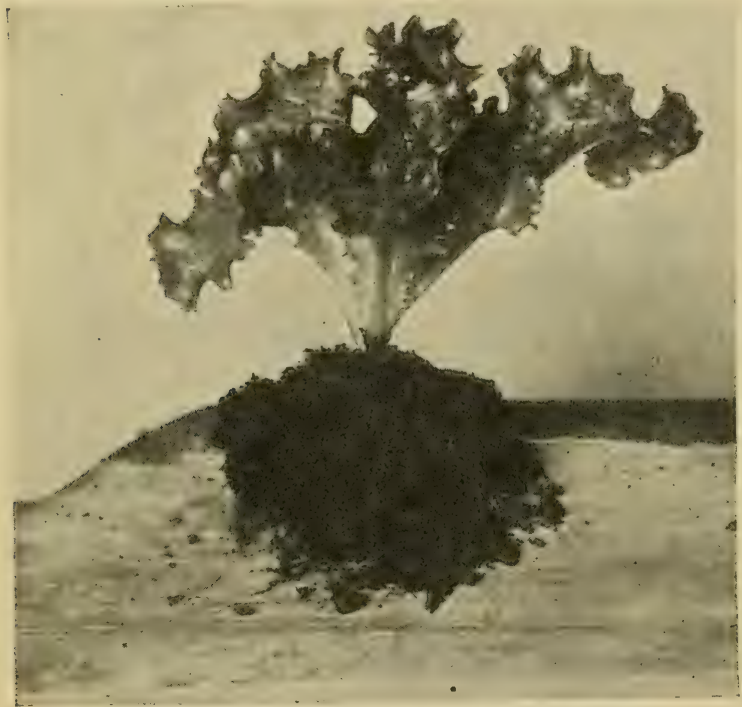

Grand Rapids lettuce plants taken from flat ready to transplant

If sown in the coldframe, grow the crop thickly and you will have many plants, small and tender. Thin out to 3 inches apart and allow the plants to make a growth. Then they may be set out in the open. 
The Grand Rapids is a good, loose-headed type and is good for early forcing; for the main crop there are a number of good varieties but one of the best known is Salamander. Curled Simpson is a secondearly crop. During the hot weather lettuce must be protected from the sun to get the best results. The romaine varieties resist the heat well.

Beets may be sown as early in the spring as the ground can be worked; as this succulent vegetable, good for both its roots and tops, is one of the hardiest grown. While the beet likes a light, sandy soil, it will grow almost anywhere if the ground is well tilled.

For an extra-early crop, seeds may be sown in boxes in February or March, and transplanted to the open ground later. The seed may be sown thickly, and as the roots grow they may be pulled to give more room for the others. Make sowings two weeks apart throughout the season. Egyptian, Eclipse, and Edmand's are three very useful varieties.

Another hardy vegetable is the pea. They may be sown as soon as the ground can be worked, but the ground should be deeply worked and thoroughly stirred. Almost any soil will do, but it should not be made too rich, as the plants will run too much to vine.

Sow only the smooth varieties first, and a little later sow the wrinkled varieties every two weeks for a. successional crop.

Plant in double rows, 6 to 8 inches apart, the rows being from 2 to 4 feet apart according to variety. 
In heavy land they may be planted early, 1 inch deep; in light, 2 inches. Later in the season the depth should be increased. Cultivation should be shallow to avoid injuring the roots and to conserve the moisture.

The dwarf and half-dwarf varieties are best for the small garden as they will need the least support. The latter may be given in form of brush or wire.

Daniel O'Rourke is best for the early crop, followed by Nott's Excelsior and Champion of England.

The tomato succumbs to frost readily, so the young plants should not be set out until May 10 or 15, in the latitude of New York.

As a general thing, manure used exclusively in a hill of rich garden soil gives too much vine growth. A dressing of nitrate of soda, acid phosphate, and muriate of potash, applied in the hill and well mixed

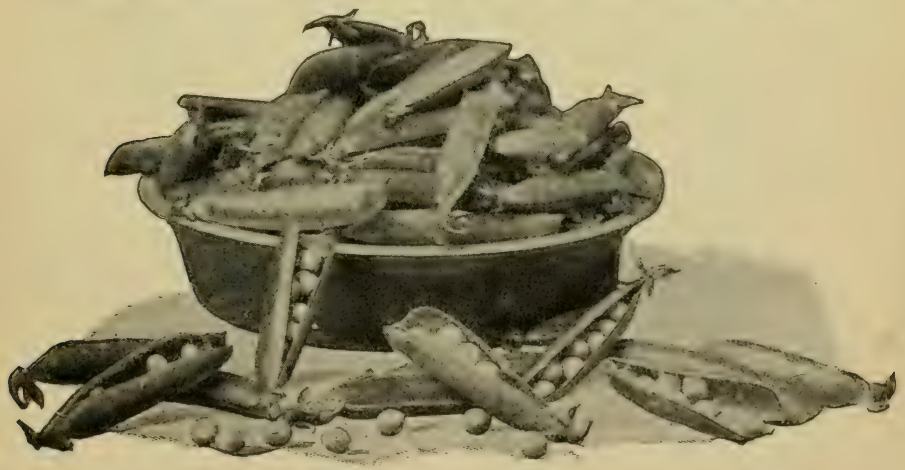

A mess of early peas 
with the soil, gives the best results. Use one-half pound of nitrate of soda, two pounds of acid phosphate, and one-half pound of muriate of potash to every ten plants. The acid phosphate and the muriate of potash may be applied in the hill and mixed with the soil before the plants are set, and the nitrate of soda applied to the surface near the plant four or five days after setting. Do not let the nitrate touch the plant.

Tomato plants should be set about 4 feet apart. Set the plants low-a trifle lower than the surface of the garden.

In garden culture, the greatest yield and best conditions for ripening the fruit are obtained by training the vines upon a pole or trellis. They should be tied to the support loosely so as not to choke the growing stem.

Tomatoes must be regularly but carefully cultivated. In working around large plants, there is danger that the fine rootlets which are to reinforce it through its bearing season may be cut. It is better to discourage weeds and conserve moisture by drawing the soil over the hill about the plants, instead of cutting into it with a hoe.

Sweet corn is one of the products of the vegetablegarden which must be eaten very quickly after it has been picked, if it is to be enjoyed to the utmost. It can be grown on any rich, well-drained soil, and it does not need to have the soil so thoroughly prepared as is necessary for some of the other garden crops, like onions, for instance, or strawberries. 


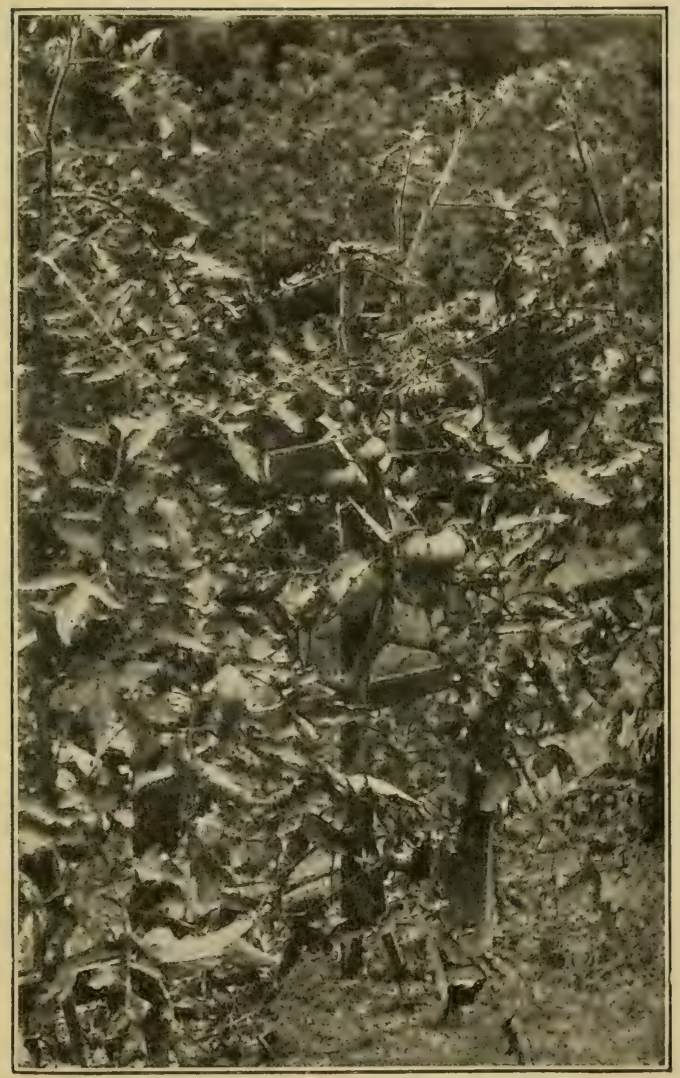

Tomato plants may be trained to stakes 


\section{HOW TO MAKE A VEGETABLE-GARDEN}

Plant the extra-early and early varieties when the cherries are in bloom; the second-early and main crops when the apples are in flower. This rule will hold true pretty much all over the country, and is better than setting any absolute dates, because it is far more accurate, being a better indication of the advance of the season.

The distance apart to plant corn varies according to the variety. If you are going to use a wheel hoe, the dwarf, extra-early forms, like Peep o'Day and Golden Bantam, should be planted as close as 2 feet, while the second-earlies should be planted 3 feet apart, and the late varieties, like Country Gentleman, 4 feet.

The earliest sweet corn worth growing is Peep o'Day, a corn which grows only $2 \frac{1}{2}$ feet high and bears two ears close to the ground. You never get this corn in market, for the market-gardener would not consider it worth growing; but for the home garden it is well worth putting in a few feet of drill of this variety, in order to get the earliest possible corn.

Golden Bantam, Early Fordhook, Early Adams, Early Cory, and the White-cob Cory are all early varieties. Golden Bantam is one of the best of these early sweet corns. It is distinguished from the other sweet corns in that the kernels are a golden yellow, which gives it its name. It is very sweet and early.

Closely following these in season come such midseason varieties as Early Cosmopolitan, Champion, Crosby's Early. There is really about a week's 
difference between these second-early, or midseason, varieties and the early. They should not be planted quite so early, either; about the time the apples are in bloom is better. Crosby's Early is probably the best variety of these second-earlies.

Country Gentleman and Stowell's Evergreen are two main-crop varieties. These are planted at the same time as the midseason varieties. Both varieties are popular. Many gardeners favor the Country Gentleman; it does not make quite so good an appearance on the table when served on the cob because the grains are not in rows, as are those of Stowell's Evergreen, but it is a very sweet corn with grains that are small, but long, and the cobs small. Good strains of this variety have ears 7 to 8 inches long, and four ears are borne to each plant. Two other good sweet varieties are White Evergreen and Stabler's Early, both deservedly popular.

Celery is easily grown in the average garden. This vegetable prefers a moist soil, but one that is well drained. The seed, being very small, should be pressed into the soil and barely covered. For the early crop the last of February or the first of March is the time to sow it in flats or coldframes. When the third or fourth leaf comes, transplant. Cut back the outside leaves and the roots, too, if they are long. Trimming leaves and roots at transplanting insures a stocky plant. Set deeply but do not cover the crown. Plant in rows 3 to 4 feet apart, with the plants 6 inches apart in the rows. Blanch by drawing up the earth in a hill and working it in around the 


\section{HOW TO MAKE A VEGETABLE-GARDEN}

plants. White Plume and Golden Self-blanching are good early varieties.

This method gives the best flavor, but boards or paper placed closely to the plants to exclude the light may be used.

The late crop may be sown out-of-doors in April. If the weather is hot and dry, shade the plants.

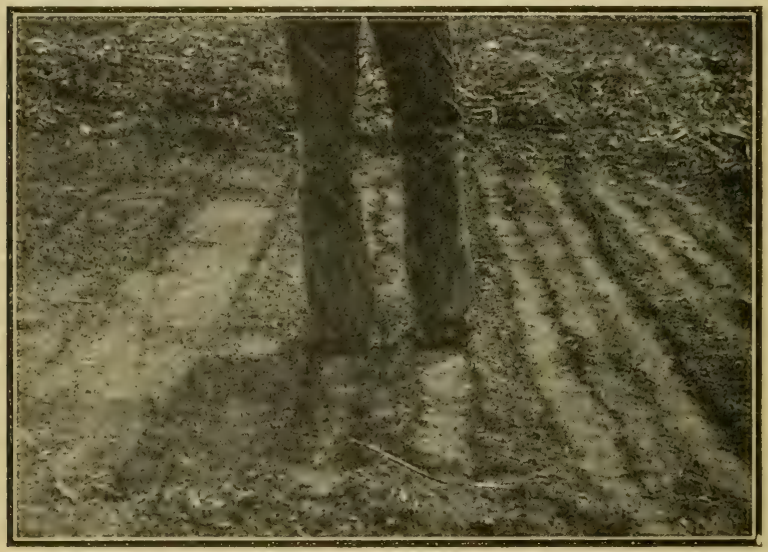

Treading-in celery seed. It is necessary that the ground be carefully firmed after the seed is sown to bring the moisture to the surface.

Transplant when the third or fourth leaf comes. Set firmly and cultivate cleanly. Blanch as for the early varieties. Celery requires a rich soil-one in which there is much nitrogen.

The bean is a tender vegetable, and should not be planted until the weather is settled and the soil warm and loose. No vegetable seed decays more 
quickly. Almost any soil will do if it be well enriched and well worked.

Beans are planted 2 inches deep and 3 inches apart, in shallow drills. Firm the ground after planting. Bush beans are planted in rows 2 feet apart and bush limas a little farther apart. Pole lima beans are generally planted in hills 2 to 4 feet apart.

The various kinds of string beans, green and wax, are planted at intervals of two weeks from the first planting until August. Of the lima beans, which take a longer season to mature, only one planting is usually made. For the small garden, the bush limas are to be preferred, as they may be planted much closer and there need be no unsightly poles. The best varieties of beans are noted in the planting table.

\section{THE LATE-STARTED GARDEN}

Every year a large proportion of amateur gardeners are confronted with the problem of starting a garden after most of the others have finished planting, and some of the early birds have even harvested some early plantings.

All the best of the vegetables, such as beans, sweet corn, muskmelons, and cucumbers, will mature good crops even when sown in June. If one is simply spending the summer in the country, and must return to the city early in September, then only the more quickly maturing kinds should be planted; but, if 
the stay is to last until cold weather sets in, a larger variety of vegetables may be grown.

The quickest-growing vegetable that one may grow is the radish. In rich, moist soil, radishes will be ready to eat in three weeks from sowing the seeds. The secret of good radishes is rapid growth; slowgrowing radishes are usually too fiery.

For flavor in salads, plant a little mustard, which will be ready for eating in thirty days, or even less. There must be frequent sowings. Lettuce sown early in June will be ready to eat in July and August. But good lettuce in summer is hard to grow, for the plants are very apt to throw out seed-stalks without having previously produced good, edible heads. If the ground is rich and moist, and the soil is stirred every three or four days, so that it has no chance to bake, good heads will be formed.

\section{KEEP LETTUCE OUT OF THE SUN}

The position in the garden where the lettuce is grown also makes a difference. Select a spot where the plants will be shaded a little from the intense midday sun. The variety also makes a difference. The crisp, heading type, of which Iceberg is the best known, stands the heat much better than the cabbage type. A good hot-weather variety of this latter type is All Seasons.

Spinach is another summer green that does not, take kindly to hot summer weather, but, if seeds of the large-leaved varieties are planted, they will 
produce good, edible leaves in July and August. An excellent substitute for the common spinach is the so-called New Zealand spinach; this is really a figwort. The tender new growths are cut off, cooked and served the same as spinach. It will stand any amount of heat and drought.

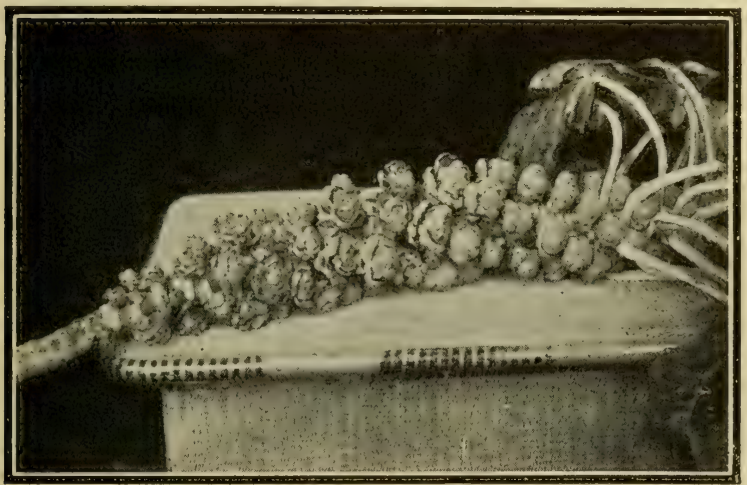

Brussels Sprouts may be planted in June

Bush beans sown early in June will bear crops in July and August, and a constant supply of tender beans may be had all summer long if more sowings are made at intervals of ten days or two weeks, and all the beans picked while they are still tender. The yellow or butter beans seem to do better during the hottest weather than green kinds, and the yellow ones are not so liable to rust as are the green varieties; in spite of this drawback, however, the latter are worth planting. Good varieties of yellow beans are Butter Wax, Round-podded Wax, Refugee and 
Stringless Wax; of green beans, Stringless GreenPod, Extra-Early Valentine and Extra-Early Refugee.

By planting an early variety of sweet corn early in Jume, edible ear's may be had in August; and at the same time sowings of the larger-eared varieties, like Stowell's Evergreen and Country Gentleman, should be made for the early fall crops. Some of the carly varieties are so good that many people make frequent plantings. Experienced gardeners prefer Crolden Bantam, a yellow variety. It is sweeter than most of the early white varieties, and a ferw successive sowings will insure an all-summer's supply.

\section{BEETS SOWN IN JUNE MATURE IN AUGUST}

Another vegetable which, if it is sown in June, will be ready to eat in August, is the beet. Use one of the early kinds, like Detroit Dark Red or Early Model; sow rather thickly, and as soon as they come up thin them out and use the thinnings for greens. These beets will be much better in August than the larger, older roots that one would buy from the green-grocer, for by this time the early-sown beets have become woody.

Like the beets, young carrots are the most luscious, but they will not be large enough to eat quite so quickly as the beets. Early June-sown carrot seeds produce good roots early in September. One should grow the small early or forcing carrots, as they are more tencler than the larger, coarser kind. 
A few plants of tomatoes should find a place in the June-planted vegetable-garden; but these must be bought, unless one has had the forethought to start the plants in the window-garden. Buy early varieties. There is no satisfaction in getting kinds that are only just coming into bearing and have a heavy crop of unripe fruit on when the frosts arrive. Such varieties as Earliana and Chalk's Early Jewel will bear earlier than most other kinds.

Cucumbers and melons are two vegetables which everybody likes to grow, and the home-picked muskmelon or cucumber can never be equaled by those that are bought in the market, because the melons must be left on the vine until they have acquired a flavor and aroma to be at their best. Cucumbers, too, to be good must be absolutely fresh. They lose their crispness in a very short time, when being shipped.

\section{GET IN SOME MELONS AND CUCUMBERS}

The middle of June is none too late in northern localities to plant the seed of melons and cucumbers. Squashes may be planted at the same time; they will mature just as early as though sown earlier.

If you wish to have a vegetable which has a good turnip flavor and yet is not so strong, grow kohlrabi. This is rather a peculiar-looking vegetahle. It is hemispherical in shape, with leaves coming at various places, unlike the turnip, all the leaves of which spring from the center. The grain is much finer 


\section{IIOW TO MAKE A VEGETABLE-GARDEN}

than that of the turnip, and the flavor is more delicate.

It is not too late to sow seeds of cabbage and cauliflower for a fall crop, but for use in the late summer

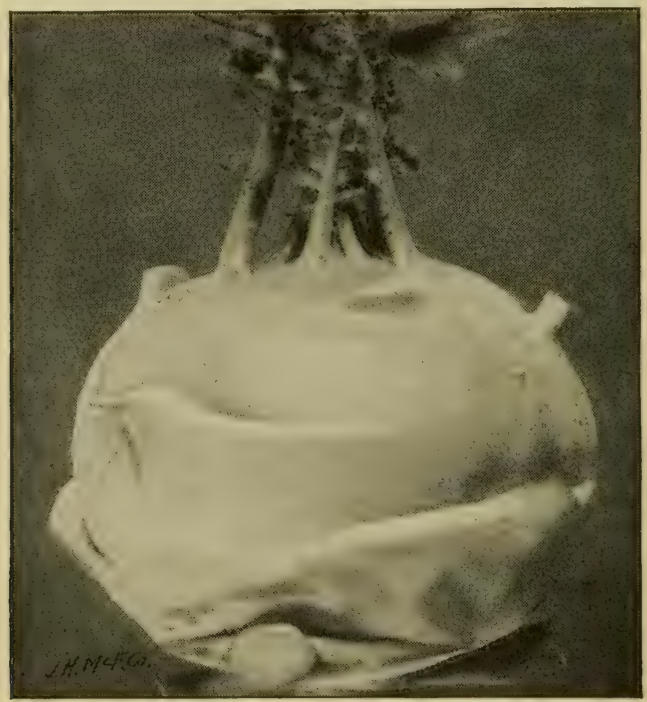

The Kohlrabi is a peculiar-looking vegetable

one should get plants. The best varieties of cauliflower for use at this time are the Extra-Early Dwarf Erfurt, Snowball, and Snowstorm. Of cabbage, any of the late kinds may be sown, and for the first crop it may be possible still to buy good plants of Early Jersey Wakefield. 
Few people in this country rexlize what a delicacy brussels sprouts are. It is a winter dish, for the sprouts do not aequire their full flavor until after the frosts of fall have touched them. In many locali-

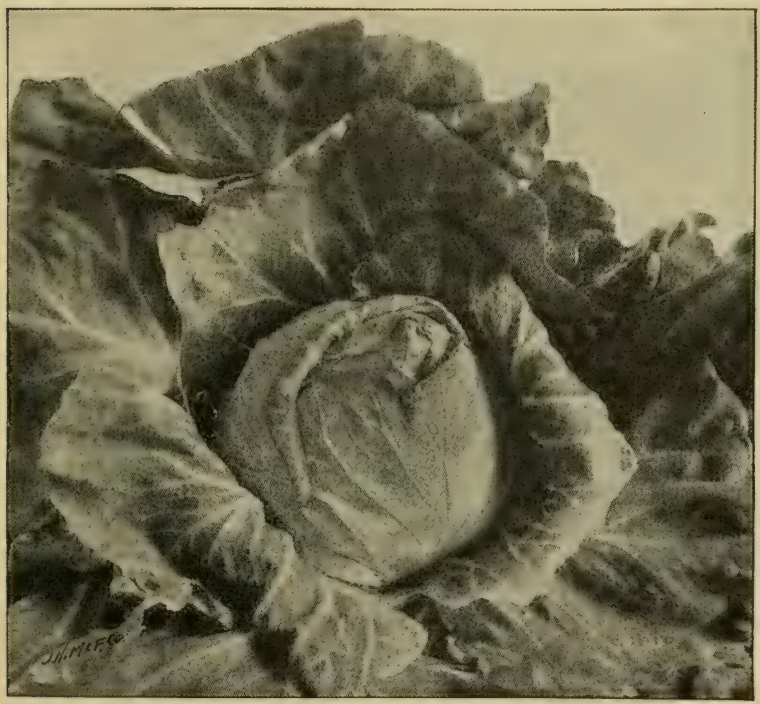

Early Jersey Wakefield Cabbage

ties the brussels sprouts have not been grown successfully, but such a variety as the Long Island Improved should succeed almost anywhere in the eastern United States. 


\section{THE GARDEN MONTH BY MONTH}

\section{JANUARY}

While no actual digging is possible, there is much garden work to be done now. A great deal of time should be devoted this month to planning the garden.

Draw on paper a plan of your proposed garden, and arrange the ground so that you will be able to utilize it the entire season.

Decide that your next garden will be a vast improvement over the last in efficiency and economy of time and labor deroted to it. This can be done only by making your plans now.

Send for the seedsmen's catalogues and make up your order early. This will help the seedsmen to give you better attention than when the rush season begins, and will also insure you that you will get all the varieties you want, and which, through unexpected demands, may be out of stock later on.

Try some vegetables that you never have undertaken to grow before. Experiments of this kind very often result in delightful surprises.

Get all of your garden tools in shape. If any parts are worn or broken, replace them now. If any tools are rusty, scrub them with benzine, and paint with white lead and lard.

$\mathrm{Now}$ is a good time to decide on any additional garden tools, so that your order may go to the manufacturers early. 


\section{FEBRUARY}

As soon as you have ordered your seeds, look over the garden tools and decide what you need to replace those that are worn out.

Sow, in greenhouse or window-garden, seeds of cabbage, cauliflower, tomatoes, and peppers for planting outdoors early.

Try some Jersey Wakefield cabbage in flats filled with light loamy soil. Sow the seed the last of the month. It should be sown thinly and covered lightly. The flats may be placed in a hotbed, or in any warm, sunny place. As soon as the plants develop, transplant to flats $1 \frac{1}{2}, 2$ inches apart, and expose to the air when the weather is favorable. They may be removed to a coldframe in March.

Sow some Prizetaker onions in flats in a hotbed or greenhouse, late in the month, and transplant to the open ground in rows one foot apart as soon as the ground is in working condition. The plants should be set 3 inches apart.

Spread heavily over your rhubarb a dressing of well-rotted manure during the latter part of the month.

If you would like some extra-early stalks of rhubarb, place a headless barrel over a few of the more sturdy plants, and pile fresh horse-manure around them. Cover the top of the barrel lightly. The satisfaction of having these early stalks will well repay you for the little time and trouble involved in the operation. 


\section{MARCH}

As soon as the ground can be worked, peas may be planted. Any of the early, smooth varieties are good for this purpose.

Spinach seeds may be planted as soon as the ground can be worked. The plants will take the place of that sown in the fall.

Do not let potatoes that have been kept for seed sprout. They must be stored in a temperature that is low, say, near the freezing point. Pick out all decayed specimens.

Toward the end of the month, sow the seeds of artichokes for next year's crop. They like a rich, deep, sandy loam. If you have old plants, give them a dressing of old, well-rotted manure, forked in.

Sow lettuce and radish seeds in the hotbed at intervals of ten days or two weeks. They will well repay you for the time and attention.

Asparagus beds will do better for a top-dressing of bone meal or other good commercial fertilizer. Barnyard manure introduces too many weed seeds.

Cover the rhubarb clumps with piles of fermenting manure if you want to force some early stalks.

\section{APRIL}

You can gain time by starting beans, both the string variety and limas, in pots, to be transplanted outcloors when all danger of frost is past. Four weeks before planting-out time is sufficient to start them. 
Another method of gaining time is to plant beans on inverted sods which, later on, can be put directly into the garden. Be sure to sow some beet seed. If you sow a row of seeds thickly, they will produce all summer. Always thin out by pulling the larger roots. The tops of young beets make excellent greens.

You can now sow cabbage and cauliflower seed out-of-doors in beds for transplanting, for the late summer and fall crops. The early plants that are in the frames should be transplanted as soon as the ground is ready for them, but be sure to harden off plants from hotbed and coldframe before transplanting them.

Celery may be sown now in seed-beds out-of-doors for the main crop.

Be sure to water carefully the eggplants that have been sown earlier, as a check to their growth now would be serious. Transplant to either paper or clay pots, but be sure the pots are large enough. Spade a good dressing of fertilizer into the asparagus bed. This work must be done carefully, so as not to injure the crowns.

A small amount of cress and mustard seeds will be useful for seasoning and salads. The plants will be ready for use in two weeks. Successive sowings should be made as long as they are wanted.

Start some muskmelons and cucumbers now, by sowing the seeds in pots in the coldframe or on inverted sods.

Parsnips and salsify that have been left in the 
ground all winter should be dug now, and stored before they start into new growth. For new crops of these vegetables, sow seeds as soon as the ground can be worked.

Soak the seeds of parsley in warm water for twenty-four hours before sowing in the ground outdoors. These seeds are very slow to germinate.

Sow smooth varieties of peas just as soon as the ground can be worked. For later plantings, use the wrinkled varieties. The ground should be prepared deeply, and should be warmer for the wrinkled than for the smooth varieties.

If you wish to get the early potatoes, use an early variety and sprout the tubers before planting them. This can be done by placing the potatoes in shallow flats and keeping them in a light, warm place.

As soon as the ground can be worked, sow both head and loose lettuce seeds outdoors.

Try some leeks. They have a more delicate flavor than onions. As soon as the plants get started, thin to 6 inches apart, and blaneh them by placing brown paper collars on them, held in place by small stakes.

If you want to have artichokes for next year, they should be started at once from seed or plants. The latter are better because named varieties can be obtained.

One row of Swiss chard will supply an ordinary family with greens all summer.

Sow spinach seeds as soon as possible, planting Long-standing, or a similar heat-resisting variety, for early summer use, 
As soon as the ground can be worked sow radish seeds. Use the turnip-rooted varicties for the early crop. They will mature in twenty days. If you want earlier crops, sow the seed in the coldframe.

Be sure that your pepper plants get careful attention, especially as to water. Transplant to paper or clay pots, and be sure that the pots are large enough.

Tomatoes in the coldframe or hotbed should be transplanted to paper pots as soon as they have good root-growth. They will make sturdier plants.

\section{MAY}

In setting out tomatoes, eggplants, and peppers, be sure that the weather is settled. Even if there is no frost, a sudden drop in temperature at night may kill them.

Do not let the rhubarb flower. Pull out the flower-stalks when they appear in the clumps.

Do not plant pole and bush lima beans too early. They will rot if the weather is cold and rainy. The ground must be quite warm to germinate them. The middle of the month will generally be found early enough.

After May 15 plant sweet corn, and then put in some more every ten days or two weeks to maintain a succession.

If you started beets under glass, now is the time to transplant them. When the ground is warm, sow outside for a succession. 
Cabbages generally do best on freshly turned sod. They should be set out before the land has had time to dry out after plowing. Cabbage needs rich land. Put on all the manure you can spare.

Toward the end of the month, plant melons in the open ground. It is useless to put them out until after settled weather has arrived. They require a rich, well-manured soil.

Be sure to provide for a succession of peas. Use first the early smooth varieties; later, plant the wrinkled kinds for two weeks. Wire poultry-netting is excellent for training up the pea-vines.

A good way of starting cucumber seeds is in inverted sods or paper pots.

If you like dandelions as a salad or greens and want some for use next spring, the seeds should be planted now. The tap-root requires a whole year to produce a good whorl of leaves.

It is wise and practical to sift dry wood-ashes on cabbage, cucumber, and squash plants before the flea beetle has had a chance to establish itself near them.

A highly recommended method of preventing the striped beetle from harming melons, cucumbers, and squashes, is to protect each hill as soon as planted with a frame covered with mosquito netting.

Don't forget that weeds will get a good start in May if you let them. The soft muggy days and frequent rains make ideal conditions for growing weeds, and you may as well squelch them at the start. 


\section{JUNE}

It is usually a practice with regard to asparagus to stop cutting the shoots when peas begin to mature. Late cutting of shoots has a tendency to weaken the plants.

It is not too late to sow a row or two of beets, in order that you may have tender, succulent roots for the fall.

The main crop of celery may be planted now, and ordinarily it will do very well to follow some of the early crops that you are harvesting.

Late cabbage and cauliflower should be set out now. These also can follow early crops.

Bear in mind that celery, cabbage, and cauliflower are heavy feeders, and will need a good deal of fertilizer.

If you sow lettuce seeds now, place them in flats in shaded places and afterward transplant to the garden. During hot weather, lettuce that has a position in a shaded place in the garden does best. Pick out a heat-resisting variety if possible.

Sow green or wax beans for ten days or two weeks, in order to maintain a succession. When the early beans have finished bearing, burn the vines, in order to prevent any ill results from fungus or insect pests.

Cucumbers and melons are warmth-loving plants and, if planted early in June, will mature almost as soon as those which were put into the ground earlier in the season.

Be sure to watch the melons already planted 


\section{HOW TO MAKE A VEGETABLE-GARDEN}

closely, so that you may fight the striped beetle as soon as it appears. It is a wise practice to cover the melon vines with cheesecloth-covered boxes until they are tough enough to withstand its ravages.

Squashes need much the same attention as melons. If you would prevent loss from the stemborer, cover the joints of the squash vines here and there with a little soil, so that they can take root.

In the northern states it is not too late to plant some melon seeds and, if the fall is a late one, a very good crop can be had.

It is also not too late to plant lima beans in the northern states. Those of the tall varieties that are already up should be trained on poles.

Be sure to provide stakes or trellises for the tomatoes. Where neither is convenient, put down some brush for the plants to run over. This will keep the fruit cleaner and drier and lessen the chances of rot.

Plan to sow some turnips for fall use. They may well take the place of some of the earlier crops.

Keep the ground about the onions well stirred and free from weeds. If onions have been sown in drills, they should be thinned to 4 or 5 inches apart.

\section{JULY}

Just because the asparagus is not a producing crop throughout the summer is no reason for neglecting it. Keep it thoroughly cultivated, and you will find that such a policy will pay you well next spring. 
July 1 is not too late to plant some okra. The pods of this vegetable are used in soups. If too many are harvested for immediate use, they may be dried for use during the winter months.

The New Zealand spinach thrives well during the hot summer months, and may be sown to take the place of the common spinach. As a rule, only the tips of the growth are eaten.

If you want to try a late sowing of peas, put in Daniel O'Rourke, but be sure to spray the vines with a fungicide, in order to keep down the mildew with which late peas are troubled.

The large radishes do better during the hot summer months than the small varieties. Try some. Certain of the varieties may be stored for winter use, and will keep fresh all winter and be as mild as the first spring radishes.

You may still set out cabbage, cauliflower, and celery plants. This, of course, may follow some early crop.

You can sow corri about July 1, if you want to take a chance on the frosts being late. Plant an early variety.

If you want lettuce seeds to germinate well during the hot summer weather, they must be sown in a moist, shaded place. Only the hot-weather-loving varieties should be planted.

Do not forget to spray potatoes with bordeaux mixture containing arsenate of lead or other arsenical poison, if you would prevent any bad effects from the blight. 


\section{HOW TO MAKE A VEGETABLE-GARDEN}

Remember that rhubarb is a gross feeder and requires plenty of manure.

IVise gardeners sow crimson clover between the rows of corn at the last cultivating. This, turned under next spring, will add humus to the soil and give you cheap nitrogen.

Continue to sow wax beans in order to maintain a succession. They can be put on the ground that has been occupied by some of the early crops like cabbage or spinach.

Sow some beets for fall use. They will be found to be remarkably tender when ready to pull.

If you spray the melons, cucumbers, and squashes with bordeaux mixture, mildew and blight will be held in check.

\section{AUGUST}

It is not too late to make a last sowing of the early table sorts of beets for a succession.

The early crop of cabbage should now be ready for harvesting. Give good cultivation to the main crop, in order to keep down the bugs and the worms.

As soon as the onions are well formed, begin to harvest them. They should lie on the ground until well cured in the air and then be placed on a barn or other floor and spread out thinly for a thorough drying.

The last crop of celery may still be set out early in the month if the rows are hoed frequently and the plants are kept growing.

Did you ever try the common drain-tiles for 
blanching celery? Put them over the plants when the latter are half-grown.

Cut the tops from the asparagus plants toward the end of the month. If you do not do this, the seeds will fall and germinate in places where they ought not to be.

Cut off the old tops of asparagus close to the ground, as the old stubs sticking up are likely to s.cratch the hands when harvesting next year's crop. Burning the tops will effectually destroy the seeds.

Cultivate the garden often. This will make a good dust mulch and conserve the moisture, and the conservation of moisture is important this month.

When you have harvested cabbage and other crops, plan for future fertilization by planting seeds of rye or of vetch and the other legumes. These can be turned in next spring, in order to make green fertilizer.

Sow every week, radishes, beans, and lettuce for a supply of fresh vegetables for the early fall.

If you would have some sweet corn at the end of the season, sow an extra-early variety before the middle of the month.

Keep up the fight against mildew and blight on squashes and melons by spraying at regular intervals with bordeaux mixture.

If your potatoes have become infested with blight, they will not keep well through the winter. Keep after the blight and the bugs by spraying with arsenate of lead in bordeaux mixture. 


\section{SEPTEMBER}

It's nearly time to get ready for winter in the vegetable-garden. Many crops inust be harvested before any damage is done by the early frosts, which come toward the end of the month.

The beets and carrots should be housed before frost. They should be stored in a cool place, and will do well if they are imbedded in sand. In storing beets, be careful not to injure them so that they bleed, because they lose in quality if they are bruised.

In banking the celery, which is an important part of the work of the month, be careful not to get earth into the heart, which will cause it to rot.

Sow some lettuce in coldframes now for fall and early winter use. It will be appreciated when so many of the other things of the garden are gone.

It is not too late to sow some radishes in coldframes.

Rhubarb should be mulched with manure. It serves a double purpose-protection for the winter and the enrichment of the ground for the next spring's crop.

If you have not already cut off the tops from the asparagus-bed, do so at once, and be sure to burn the tops.

Another wise precaution is to collect all of the melon and squash vines as soon as they are through bearing and burn them. Some gardeners defer this operation until the vines have been killed by frost. As the garden approaches the end of the season, 
keep it cleaned up. All refuse and dead vines and plants should be gathered and burned. You are then sure that any insect pests which they may be harboring are destroyed.

Be sure to store the squashes and pumpkins in a cool, dry place, but one that is free from frost.

Both the shell and lima beans should be picked before the frosts kill the plants. They may be then shelled and dried for winter use.

After digging the potatoes, dry them for a few hours. Put them into bags and store them for a few days in an airy place, and then they are ready for the cellar.

Growers of sweet potatoes find that they will keep better if dug before the vines are touched with the frost. They have to be sweated before being stored.

\section{OCTOBER}

Get the celery out of the ground.

Dig chicory, and store in damp sand.

Clean and fertilize the asparagus patch.

Blanch endive by tying the tips together.

If you have no asparagus, set sut some now.

White grub is easily destroyed by fall spading.

Transplant some parsley into window-boxes for winter use.

Start a rhubarb-patch this month, and mulch well with manure.

Clean up all cabbage stumps. They provide excellent shelter for cabbage worms. 
Parsnips should not be harvested, excepting as wanted for use. They have a better flavor if left in the ground.

If you have plenty of asparagus and rhubarb, dig up some of the roots for forcing in the cellar. The furnace heat will do it.

Squash bugs can be found under boards laid in the garden, and thus easily destroyed. They seek shelter under the boards during the night.

Spade up the garden and leave it rough over winter. Many pests, including cutworms, will be destroyed by the loosening up of the ground and consequent destruction of their cells.

\section{NOVEMBER}

If you have planted spinach, give it a light mulch of litter or straw. Use just enough to hold a little snow and prevent alternate thawing and freezing.

Your rhubarb should have a mulch of good, wellrotted manure. Rhubarb is a gross feeder, and the mulch will serve the double purpose of winter protection and soil nourishment.

Now is a good time to attend to hotbed repairs and repainting. Gather all the sash not in use and store in a dry place.

Before putting your garden tools in winter quarters, look them over and order renewals for any broken parts. If any of the tools are rusty, scour them and paint with a thin coating of three parts of lard and one part of powdered resin, melted together. 
Some gardeners use lard containing a little white lead.

The wooden parts of tools look better and last longer if given a coat of good paint and linseed oil once a year.

One good way to keep celery for the winter is to put it in a trench lined and built up with boards and covered with soil. Upon the approach of severe weather, straw or manure should be put over the trench.

Beets will keep well in pits out-of-doors, but a few may be stored in the cellar if placed in damp sand, to prevent shriveling.

Asparagus and rhubarb for foreing indoors can be taken up successfully until the ground is frozen hard.

Clean up the garden thoroughly, so that there will be no places for injurious insects to breed. If you plow up the garden in ridges, leaving the land loose, the frost working through the soil will kill many of the pests. 


\section{A PLANTING TABLE}

After studying planting tables of many kinds, we are convinced that the amateur will find this the most helpful and practical table for planting vegetables which has ever been published. In using the table, allow ten days for every one hundred miles north or south.

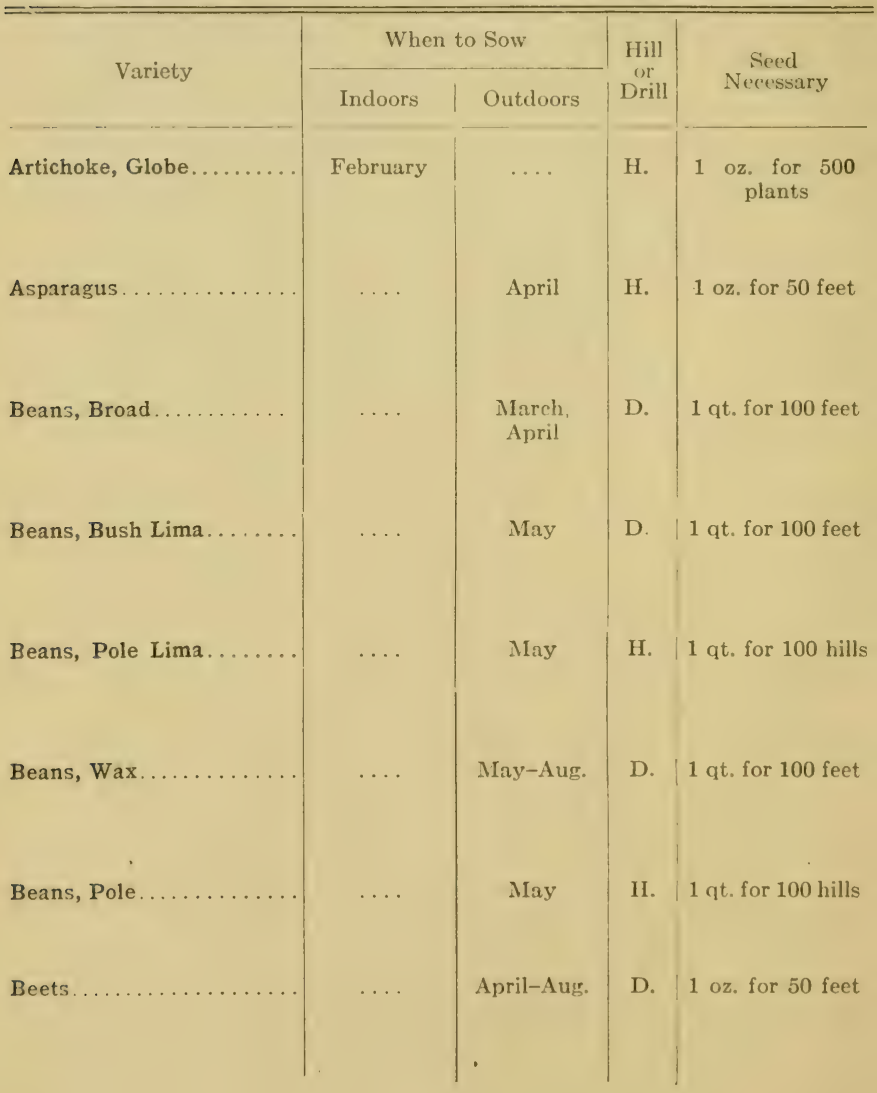




\section{FOR VEGETABLES}

of the latitude of New York City. If this table is earefully followed throughout the summer, it will make it posisible for the amateur to have a constant sucersion of vegetables until late in the fall. When selecting varieties, it is best to consult the local seedsmen.

How Deep to Plant (inches) R. $=$ roots S. $=$ seeds

S. 1

R. 6

$36 \times 3 !$

$12 \times 24$

$6 \times 12$

$24 \times 36$

Transplant to (inches)

$24 \times 36$

Sieptember

April-June

June, Iuly

Aug. to frost

Aug, to frost

$12 \times 24$

July on

$36 \times 36$

$11 / 2$
Aug. to frost

July on

\section{('ultural Information}

Freneh Gilobe is the standard sort. Grow in rich soil. Is grown for the flower-heads, which are gathered before they open. Bears for two or three years if given slight protection. Barr's Manmoth, Colossal, and Palmetto, best green varieties. Mammoth White has whitestalks. Needs rich soil. Cut bed lightly first season. Cut off and burn stalks in fall.

As hardy as peas. For early erop plant Early Mazagan; main crop, Broad Windsor. When pods have formed, break off top of plant to force strength into pods.

For early crop plant Henderson's; second early, Dreer's; main crop, Large Bush. Plant the "eye" down. Use commercial fertilizer in row. Needs warm land.

For early crop plant Early Sieva; second early, Early Jersey; main crop, Large White; late crop, Dreer's Pole. Use 10-foot poles and plant them before putting in the beans.

For early erop plant Early Valentine; second early, Refugee Wax; main crop, Golden Wax; late crop, Early Valentine. Sow every two weeks for suceession.

For early erop plant Kentucky Wonder. Dutch Caseknife and Lazy Wife are good, but later. All will bear until frost.

For early crop, Egyptian; second early, Eclipse; main crop, Edmand's; late erop, Egyptian. Sow early varieties every two weeks, using beets when small and tender. 


\begin{tabular}{|c|c|c|c|c|}
\hline \multirow{2}{*}{ Variety } & \multicolumn{2}{|c|}{ When to Sow } & \multirow{2}{*}{$\begin{array}{c}\text { Hill } \\
\text { or } \\
\text { Drill }\end{array}$} & \multirow{2}{*}{$\begin{array}{c}\text { Seed } \\
\text { Necessary }\end{array}$} \\
\hline & Indoors & Outdoors & & \\
\hline Broccoli........ & $\ldots$ & April & II. & $\begin{array}{l}1 \text { oz. for } 2,000 \\
\text { plants }\end{array}$ \\
\hline Brussels Sprouts.. & $\ldots$ & April, May & $\mathrm{H}$. & $\begin{array}{l}1 \mathrm{oz} \text {. for } 2,000 \\
\text { plants }\end{array}$ \\
\hline Cabbage....... & Feb., Mar. & May, June & H. & $\begin{array}{l}1 \mathrm{oz} \text {. for } 2,000 \\
\text { plants }\end{array}$ \\
\hline Cardoon....... & $\ldots$ & May, June & H. & $\begin{array}{l}1 \text { oz. for } 300 \\
\text { plants }\end{array}$ \\
\hline Carrot.......... & $\ldots$ & April-July & D. & $1 \mathrm{oz}$. to 100 feet \\
\hline Cauliflower..... & $\ldots$ & $\ldots$ & H. & $\begin{array}{l}1 \mathrm{oz} \text {. for } 2,000 \\
\text { plants }\end{array}$ \\
\hline Celery.......... & February & April, May & D. & $\begin{array}{l}1 \mathrm{oz} \text {. for } 2,000 \\
\text { plants }\end{array}$ \\
\hline Chard, Swiss... & $\ldots$ & April & D. & $1 \mathrm{oz}$. for 50 feet \\
\hline Corn.......... & April & May, June & II. & $\begin{array}{l}1 \text { quart for } 100 \\
\text { hills }\end{array}$ \\
\hline
\end{tabular}




\begin{tabular}{|c|c|c|c|}
\hline $\begin{array}{l}\text { How Deep } \\
\text { to Plant } \\
\text { (inches) } \\
\mathrm{R} .=\text { roots } \\
\mathrm{S} .=\text { seeds }\end{array}$ & $\begin{array}{l}\text { Thin or } \\
\text { Transplant } \\
\text { to (inches) }\end{array}$ & $\begin{array}{l}\text { Season of } \\
\text { Crop }\end{array}$ & Cultural Information \\
\hline $1 / 2$ & $24 \times 36$ & July to Oct. & $\begin{array}{l}\text { Similar to cauliflower, but better } \\
\text { adapted than it for the cool North. } \\
\text { For early crop grow Early White; } \\
\text { main crop, Mammoth White or } \\
\text { Purple Cape. }\end{array}$ \\
\hline $1 / 2$ & $18 \times 36$ & October on & $\begin{array}{l}\text { Good varieties are Long Island, Sal- } \\
\text { keith, Half-Dwarf. Not good until } \\
\text { touched by frost. Are hardy, so } \\
\text { may be left outdoors during winter if } \\
\text { protected with straw or cornstalks. }\end{array}$ \\
\hline $1 / 2$ & $24 \times 36$ & July on & $\begin{array}{l}\text { For early, plant Early Jersey Wake- } \\
\text { field; second early, All-Head; main } \\
\text { crop, Late Flat Dutch. Late crop } \\
\text { can be planted on land on which } \\
\text { early peas were grown. }\end{array}$ \\
\hline 1 & $24 \times 36$ & August on & $\begin{array}{l}\text { Good varieties are Large Spanish, } \\
\text { Large Solid. Grow on rich ground. } \\
\text { When } 3 \text { feet high tie tops together, } \\
\text { protect with straw and draw earth } \\
\text { about stems to blanch. }\end{array}$ \\
\hline $1 / 2$ & $6 \times 18$ & July on & $\begin{array}{l}\text { For early crop plant Early Forcing; } \\
\text { second early, main crop, Danvers; } \\
\text { late crop, Early Forcing. For con- } \\
\text { tinuous crop of small tender roots } \\
\text { sow bi-weekly. }\end{array}$ \\
\hline $1 / 2$ & $24 \times 18$ & July to Oct. & $\begin{array}{l}\text { For earliest crop sow earliest Dwarf } \\
\text { Erfurt; second early, Early Snowball; } \\
\text { main crop, Algiers; late crop, Earliest } \\
\text { Dwarf Erfurt. Needs cool weather } \\
\text { and rich, moist soil. }\end{array}$ \\
\hline $1 / 4$ & $6 \times 48$ & August on & $\begin{array}{l}\text { For earliest crop grow White Plume; } \\
\text { second early, Golden Self-blanching; } \\
\text { main crop, Giant Pascal. Give an } \\
\text { abundance of a nitrogenous manure } \\
\text { like nitrate of soda. }\end{array}$ \\
\hline $11 / 2$ & $9 \times 24$ & June to frost & $\begin{array}{l}\text { No choice as to varieties. Commence } \\
\text { cutting when leaves are } 6 \text { inches } \\
\text { high. New leaves will be formed. } \\
\text { Cook and serve like beet greens. }\end{array}$ \\
\hline $11 / 2$ & $36 \times 36$ & Aug. to frost & $\begin{array}{l}\text { For early plant Peep o'Day; second } \\
\text { early, Golden Bantam; midseason, } \\
\text { Crosby's Twelve-rowed; main crop, } \\
\text { plant every two weeks, Stowell's } \\
\text { Evergreen. }\end{array}$ \\
\hline
\end{tabular}


A PLANTING TABLE

\begin{tabular}{|c|c|c|c|c|}
\hline \multirow{2}{*}{ Variety } & \multicolumn{2}{|c|}{ When to Sow } & \multirow{2}{*}{$\begin{array}{l}\text { Hill } \\
\text { or } \\
\text { Drill }\end{array}$} & \multirow{2}{*}{$\begin{array}{c}\text { Seed } \\
\text { Necessary }\end{array}$} \\
\hline & Indoors & Outdoors & & \\
\hline Corn Salad ............ & $\ldots$ & April-Aug. & D. & $1 \mathrm{oz}$. for 100 feet \\
\hline Cress................. & ... & April-July & D. & $1 \mathrm{oz}$. to 50 feet \\
\hline Cucumber............. & March & May-July & H. & $1 \mathrm{oz}$. to 50 hills \\
\hline Dandelion.............. & $\ldots$ & April & D. & $\begin{array}{l}1 \text { oz. for } 1,000 \\
\text { plants }\end{array}$ \\
\hline Eggplant........... & Feb., March & $\cdots$ & H. & $\begin{array}{l}1 \mathrm{oz} \text {. for } 1,000 \\
\text { plants }\end{array}$ \\
\hline Endive........... & ... & April-Sept: & D. & $1 \mathrm{oz}$. for 150 feet \\
\hline Kale................. & $\ldots$ & May & D. & $1 \mathrm{oz}$. for 150 feet \\
\hline Kohlrabi.............. & $\ldots \ldots$ & May, June. & D. & $1 \mathrm{oz}$. for 200 feet \\
\hline Lettuce....... & Feb., March & April-Aug. 1 & D. & $1 \mathrm{oz}$. for 120 feet \\
\hline
\end{tabular}


FOR VEGETABLES, continued

\begin{tabular}{|c|c|c|c|}
\hline $\begin{array}{l}\text { How Deep } \\
\text { to Plant } \\
\text { (inches) } \\
\text { R.= roots } \\
\text { S. = seeds }\end{array}$ & $\begin{array}{l}\text { Thin or } \\
\text { Transplant } \\
\text { to (inches) }\end{array}$ & $\begin{array}{l}\text { Season of } \\
\text { (Crop) }\end{array}$ & Cultural Information \\
\hline $1 / 4$ & $6 \times 6$ & June on & $\begin{array}{l}\text { Grown mostly for fall salad. Good } \\
\text { substitute for lettuce. Will live } \\
\text { outdoors all winter if given a pro- } \\
\text { tection of straw or leaves. }\end{array}$ \\
\hline $1 / 4$ & $3 \times 6$ & June on & $\begin{array}{l}\text { Of the garden cress sow Curled or } \\
\text { Upland every two weeks; when } \\
\text { cut it will grow again; water cress } \\
\text { can be grown in damp soil as well as } \\
\text { in water. }\end{array}$ \\
\hline $1 / 2$ & $36 \times 36$ & July to frost & $\begin{array}{l}\text { For early crop grow Early White } \\
\text { Spine; second early, Cool and Crisp; } \\
\text { main crop, Long Green. Start a few } \\
\text { plants indoors on inverted sods. }\end{array}$ \\
\hline $1 / 4$ & $12 \times 18$ & $\begin{array}{l}\text { Following } \\
\text { spring }\end{array}$ & $\begin{array}{l}\text { Grown for pot herb. They are greatly } \\
\text { improved by blanching, which is } \\
\text { done by covering with an A-shaped } \\
\text { trough. Good varieties are French } \\
\text { Garden, Thick-leaved, Large-leaved. }\end{array}$ \\
\hline $1 / 2$ & $36 \times 36$ & Aug. to frost & $\begin{array}{l}\text { New York Spineless is the best va- } \\
\text { riety. Do not set plants in garden } \\
\text { until ground is thoroughly warm and } \\
\text { there is no danger of frost. }\end{array}$ \\
\hline 14 & $12 \times 12$ & $\begin{array}{l}\text { Seipt. through } \\
\text { winter }\end{array}$ & $\begin{array}{l}\text { For early, sow White Curled; main } \\
\text { crop, Green Curled or Broad-leaved. } \\
\text { Make successive sowing every two or } \\
\text { three weeks. For winter use store } \\
\text { plants in the cellar. }\end{array}$ \\
\hline 16 & $12 \times 15$ & September & $\begin{array}{l}\text { Grow and grive the same attention as } \\
\text { for cabbage. Good varieties are } \\
\text { Dwarf Green, Curled Scoteh, Dwarf } \\
\text { Curled Brown. Sow Siberian in } \\
\text { September for early "greens." }\end{array}$ \\
\hline $1 / 2$ & $12 \times 24$ & Aug., Sept. & $\begin{array}{l}\text { For early crop grow Short-leaved } \\
\text { Parly White Vienna or Early } \\
\text { Purple Vienna in frames; main crop, } \\
\text { Early White Vienna. Gather when } \\
\text { bulbs are } 3 \text { inches in diameter. }\end{array}$ \\
\hline $1 / 4$ & $8 \times 24$ & June to frost & $\begin{array}{l}\text { For early, grow Grand Rapids, a loose- } \\
\text { head; second early, Curled Simpson; } \\
\text { main crop, Salamander. During } \\
\text { hot weather protect lettuce from } \\
\text { hot midday sun. }\end{array}$ \\
\hline
\end{tabular}




\section{A PLANTING TABLE}

\begin{tabular}{|c|c|c|c|c|}
\hline \multirow{2}{*}{ Variety } & \multicolumn{2}{|c|}{ When to Sow } & \multirow{2}{*}{$\begin{array}{c}\text { Hill } \\
\text { or } \\
\text { Drill }\end{array}$} & \multirow{2}{*}{$\begin{array}{c}\text { Seed } \\
\text { Necessary }\end{array}$} \\
\hline & Indoors & Outdoors & & \\
\hline Lettuce, Romaine. & $\cdots$ & April-July & D. & $1 \mathrm{oz}$. for 100 feet \\
\hline Melon, Musk.... & April & May, June & II. & $1 \mathrm{oz}$. for 60 hills \\
\hline Melon, Water.... & $\cdots$ & May & H. & $1 \mathrm{oz}$. for 30 hills \\
\hline Mustard & $\ldots$ & April, May & D. & 1 oz. for 80 feet \\
\hline Okra...... & Mareh & May. & D. & $1 \mathrm{oz}$. for 40 feet \\
\hline Onion........ & February & April & 1). & $\begin{array}{l}\text { S., } 1 \text { oz. for } 100 \\
\text { feet } \\
\text { Sets, } 1 \text { qt. for } \\
50 \text { feet }\end{array}$ \\
\hline Parsley........... & $\ldots$ & April & D. & $1 \mathrm{oz}$. for 150 feet \\
\hline Parsnip.......... & $\ldots$ & April & 1). & $1 \mathrm{oz}$. for 200 feet \\
\hline
\end{tabular}


FOR VEGETABLES, continued

\begin{tabular}{|c|c|c|}
\hline $\begin{array}{l}\text { How Deep } \\
\text { to Plant } \\
\text { (inches) } \\
\mathrm{R} \text {.= roots } \\
\mathrm{S} .=\text { seeds }\end{array}$ & $\begin{array}{l}\text { Thin or } \\
\text { Transplant } \\
\text { to (inches) }\end{array}$ & $\begin{array}{c}\text { Season of } \\
\text { Crop }\end{array}$ \\
\hline $1 / 4$ & $8 \times 24$ & July to frost \\
\hline 1 & $60 \times 60$ & Aug. to frost \\
\hline 1 & $60 \times 60$ & Aug. to frost \\
\hline $1 / 4$ & $1 \times 6$ & $\begin{array}{c}\text { Ready in four } \\
\text { wecks }\end{array}$ \\
\hline $11 / 2$ & $18 \times 24$ & July to frost \\
\hline $\begin{array}{l}\text { S. }{ }^{1} 2 \\
\text { R. } 2\end{array}$ & $\begin{array}{r}12 \times 24 \\
6 \times 24\end{array}$ & May on \\
\hline $1 / 2$ & $6 \times 12$ & May on \\
\hline $1 / 2$ & $6 \times 24$ & $\begin{array}{c}\text { Sept. through } \\
\text { winter }\end{array}$ \\
\hline
\end{tabular}

Express Cos, Trianon Cos good varieties. Blanch by tying leaves together with raffia. Seem to resist heat well. Need deep, rich soil and plenty of nitrogenous manure.

For early, Netted Gem; second early, Emerald Gem; main crop, Long Island Beauty. Prefer a moist, sandy soil. Spray with bordeaux mixture to prevent blight and mildew.

For early crop, Early Fordhook; second-early, Cole's Early; main crop, Cuban Queen. Watermelons prefer a light, sandy, but moist soil. Spray with bordeaux mixture.

Good varieties are Chinese or White London. Make successive sowings every ten days or two weeks. Mustard adds a pleasant, pungent flavor to salads.

Good varieties, Dwarf Prolific; White Velvet, Long Green, Used for flavoring Gumbo soup. Pick pods when 1 to 2 inches long. Surplus can be dried or canned.

For earliest crop, plant onion sets; for main crop, White Globe or Prizetaker. Latter variety started early under glass and transplanted to open in May.

Good varieties, Moss Curled, Fernleaved. Used for garnishers: Soak seed for several hours in lukewarm water to hasten germination. Hamburg or Turnip-rooted has fleshy root.

For early, plant Early Round; main crop, Hollow Crown. Much improved by keeping over winter in ground. To be available at any time, give mulch. 
A PLANTING TABLE

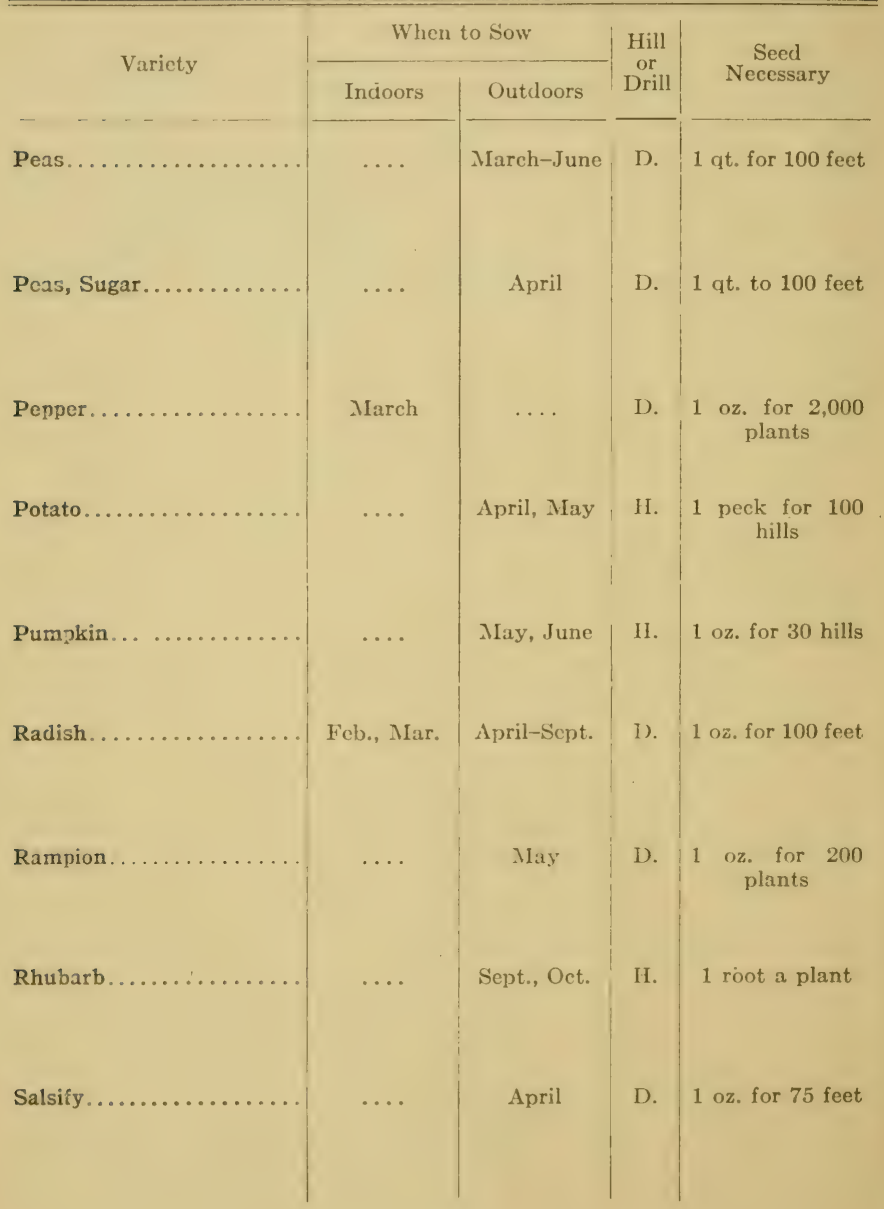


FOR VEGETABLES, continued

\begin{tabular}{|c|c|c|c|}
\hline $\begin{array}{l}\text { How Deep } \\
\text { to Plant } \\
\text { (inches) } \\
\mathrm{R} .=\text { roots } \\
\mathrm{S} .=\text { seeds } \\
\end{array}$ & $\begin{array}{l}\text { Thin or } \\
\text { Transplant } \\
\text { to (inches) }\end{array}$ & $\begin{array}{l}\text { Season of } \\
\text { Crop }\end{array}$ & Cultural Information \\
\hline 3 & $4 \times 36$ & June to frost & $\begin{array}{l}\text { For early crop, Daniel O'Rourke; } \\
\text { second early, Nott's Excelsior; main } \\
\text { crop, Champion of England; late, } \\
\text { Daniel O'Rourke. Late crop subject } \\
\text { to mildew. }\end{array}$ \\
\hline 3 & $4 \times 36$ & July & $\begin{array}{l}\text { These are edible-podded peas which } \\
\text { are picked while the pea or seed is } \\
\text { still small and the pod tender. They } \\
\text { are broken up, cooked, and served } \\
\text { like string beans. }\end{array}$ \\
\hline $1 / 2$ & $18 \times 36$ & July to frost & $\begin{array}{l}\text { For early, plant Neapolitan; second- } \\
\text { early, Bullnose; main crop, Ruby } \\
\text { King. Neapolitan has a very sweet } \\
\text { flesh and is the best for cooking. }\end{array}$ \\
\hline $\begin{array}{l}2 \text {, early } \\
5 \text {, late }\end{array}$ & $\begin{array}{l}12 \times 24 \\
18 \times 36\end{array}$ & July on & $\begin{array}{l}\text { For early crop, Early Rose; second } \\
\text { early, Beauty of Hebron; main crop, } \\
\text { Carman No. 1, or Green Mountain. } \\
\text { Spray with bordeaux mixture and } \\
\text { paris green every two weeks. }\end{array}$ \\
\hline $11 \frac{1}{2}$ & $108 \times 108$ & September & $\begin{array}{l}\text { Two good varieties for pies are Sugar } \\
\text { and Dunkard. Must be stored in a } \\
\text { warm }\left(45^{\circ}\right) \text {, dry place or they will } \\
\text { rot. Plant among corn to save room. }\end{array}$ \\
\hline $1 / 2$ & $3 \times 8$ & $\begin{array}{l}\text { Mature in } 25 \\
\text { days }\end{array}$ & $\begin{array}{l}\text { For early, plant early Scarlet Turnip } \\
\text { Forcing; second, French Breakfast } \\
\text { and Long Scarlet. For winter, } \\
\text { Half-Long Black Spanish. Make } \\
\text { successive sowings once a week. }\end{array}$ \\
\hline $1 / 8$ & $3 \times 8$ & Oct. to Feb. & $\begin{array}{l}\text { Roots can be eaten like radishes, or } \\
\text { they and the leaves can be served in } \\
\text { salads. Store roots in damp sand } \\
\text { in cellar. It has the smallest seed of } \\
\text { any vegetable. }\end{array}$ \\
\hline R. 4 & $48 \times 48$ & May to July & $\begin{array}{l}\text { Linnaeus, Victoria, St. Martins are } \\
\text { all good varieties. To get the earliest } \\
\text { rhubarb, put headless barrel over } \\
\text { plant and surround it with fresh } \\
\text { horse manure. }\end{array}$ \\
\hline $11 / 2$ & $6 \times 8$ & $\begin{array}{l}\text { Sept. through } \\
\text { winter }\end{array}$ & $\begin{array}{l}\text { Long White and Sandwich Island } \\
\text { Mammothare good varieties. Hardy. } \\
\text { Store over winter in cellar packed } \\
\text { in damp sand. Used to flavor soups, } \\
\text { stews, etc. }\end{array}$ \\
\hline
\end{tabular}


A PLANTING TABLE

\begin{tabular}{|c|c|c|c|c|}
\hline \multirow{2}{*}{ Variety } & \multicolumn{2}{|c|}{ When to Sow } & \multirow{2}{*}{$\begin{array}{c}\text { Hill } \\
\text { or } \\
\text { Drill }\end{array}$} & \multirow{2}{*}{$\begin{array}{c}\text { Seed } \\
\text { Necessary }\end{array}$} \\
\hline & Indoors & Outdoors & & \\
\hline 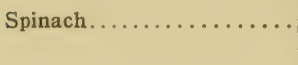 & $\ldots$ & $\begin{array}{c}\text { Mar.-May } \\
\text { October }\end{array}$ & D. & $1 \mathrm{oz}$. for 100 feet \\
\hline Spinach, New Zealand..... & $\ldots$ & May & D. & $1 \mathrm{oz}$. for 100 feet \\
\hline Squash............... & March & May, June & H. & $1 \mathrm{oz}$. for 50 hills \\
\hline 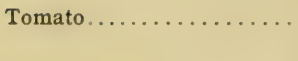 & Feb.-April & $\ldots$ & $H$. & $\begin{array}{c}1 \mathrm{oz} \text {. for } 100 \\
\text { plants }\end{array}$ \\
\hline Turnip............... & $\ldots$ & April-Aug. & D. & $1 \mathrm{oz}$. for 150 feet \\
\hline Vegetable Marrow........ & $\ldots$ & May, June & $\mathrm{H}$. & 1 oz. to 50 hills \\
\hline
\end{tabular}


FOR VEGETABLES, continued

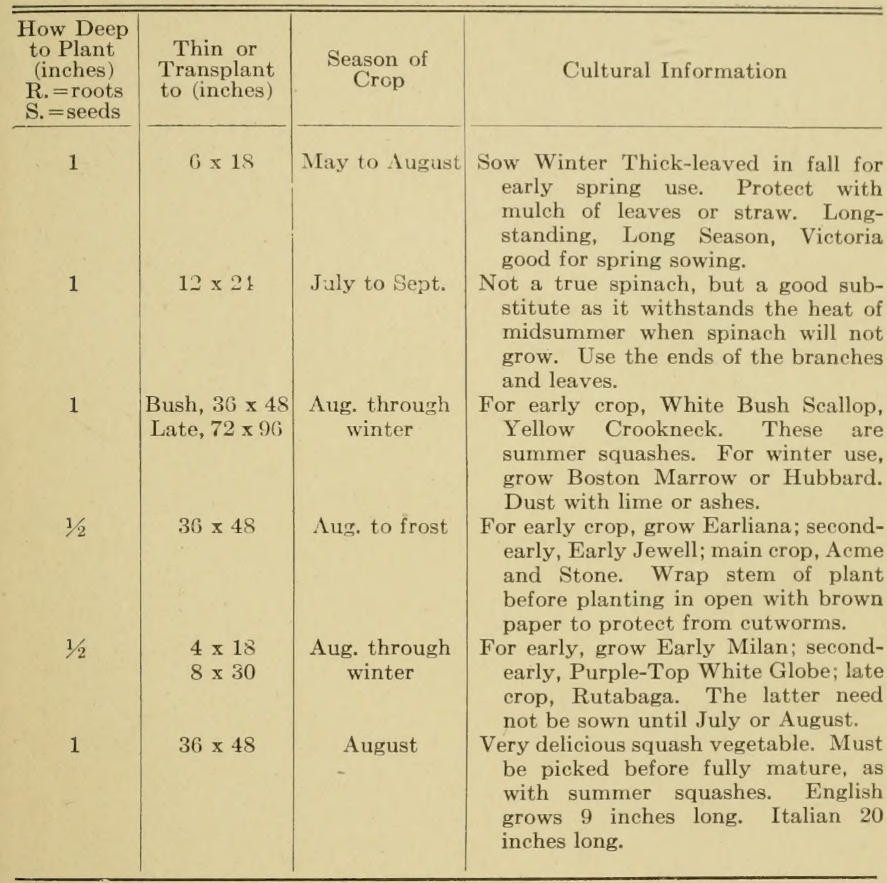




